\begin{tabular}{|l||c|c||}
\hline \hline Received 26.06.2020 & & JOTS \\
\hline Accepted 02.07.2020 & Research Article & 2021: $96-140$ \\
\hline \hline Published 10.01.2021 & & \\
\hline
\end{tabular}

Yaşın yaşın ağlar mısın (Yunus Emre)

\title{
Buruldum-ise Saraldum-ise: Dede Korkut Kitabi'nın Günbed Yazmasında Bir Soylama Başlangıcı Yahut Bulut Olmak Hakkında
}

\author{
Buruldum-isä Saraldum-isä: The Introduction of a Declamation in the Gonbad Manuscript of \\ Dädä Qorqut or about the Being Cloud
}

\author{
Aslıhan HAZNEDAROĞLU* \\ Düzce University (Düzce/Turkey) \\ E-mail: aslihankaragoz@duzce.edu.tr
}

Dresden and Vatican manuscripts as a text based on declamation (soylama). 17th declamation, which is included in the manuscript and which also includes the story of Kazan's heroics, is noted as expressed in the language of Qazan. In this declamation, Salur Qazan started describing himself with a metaphorical saying that he was 'cloud, smoke and misty'. Beginning of the declamation with words about the sky in this way is in harmony with the other declamations in the text. However, in order to resolve these words, it will be necessary to understand the expression of burulma and saralma and what it means by being a 'cloud'. According to our study, burulmaq and saralmaq is an expression parallel to be angry and the cloud is part of the stereotypes about intimidating the enemy. Such as the lion's roar, the roar of the cloud is a symbol of wrath which is a glorified feature of heroes. The word bulut 'cloud' that describes Qazan, should be considered with the accolades used for Qazan such as kara bulut örgüni 'black cloud thunder?' and dumanlı dağ börisi 'the wolf of the smoky mountain'.

Key Words: Dädä Qorqut, Gonbad, Salur Qazan, mythology, wrath, bura sara, burulma, cloud.

\footnotetext{
ORCID ID: 0000-0002-0778-6101.
} 


\section{J(৫)}

\section{Giriş}

Veli Muhammed Hoca isimli bir kitapseverin Tahran'daki kitapçı arkadaşından satın alarak gün yüzüne çıkmasına aracı olduğu Dede Korkut Kitabı'nın üçüncü yazması, 2019 yılının önemli bir kültür sanat olayı olmuştur. Dresden ve Vatikan yazmalarının keşfinden uzun yıllar sonra ortaya çıkmış olan bu yeni yazma, ülkemizde birbirinden bağımsız yürütülen üç çalışma ile bilim dünyasına tanıtılmış, diğer Türk cumhuriyetlerinde de ilgili yayınlar yapılmıştır. Bugün yeni yazmanın okunuşu ve anlamlandırılmasıyla ilgili çalışmaların sayısı 10'a ulaşmıştır. Bu öncü çalışmaları şu şekilde sıralayabiliriz: Azmun 2019, Ekici 2019, Shahgoli et al. 2019, Asker 2019, Haciyev 2019, Serrafî et al. 2019, Quliyev 2020, Rafraf 2020, Rzasoy 2020, Tulu 2020. ${ }^{1}$ Günümüz Türkçesine aktarımda ve geniş inceleme bölümüyle Azmun ve Ekici ile Shahgoli et. al.'in çalışmaları öncü olmayı sürdürmektedir. Türkiye dışındaki ilk neşir Asker'in neşridir. Sarrafi et. al.'in çalışması harita, sözlük ve toponim bilgisi yönünden dikkat çeker. Sarrafi et. al ile Rafraf neşri, Arap ve Latin harflerinde düzenlenmiştir. Hacıyev ve Rzasoy'un çalışmaları metni anlamaya ve yorumlamaya yöneliktir. Quliyev neşrinde yazma hakkında genel değerlendirmeler yapılmıştır. Tulu yeni yazmanın günümüz Türkçesine sözlü çevirisini, önceki iki yazma ile birlikte yayımlamıştır. Hemen bütün çalışmalar sözlüğe ve dipnotta açılamalara yer vermekte ve alana önemli bir katkı sunmaktadır. Yazmanın İngilizce çevirisi de ilk yayının sahibi Azmun tarafından hazırlanmaktadır. ${ }^{2}$ Böylece okuyucuların yeni yazmayla temasında önemli bir zenginlik ortaya çıkmıştır.

Bir Azerbaycanlı tarafından eski bir yazmadan kopya edildiği düşünülen eserin okunuşu konusunda bazı ihtilaflar söz konusudur. İstinsah ve mürekkep kaynaklı kusurlar da bu ihtilafları arttıran bir husustur. Her çalışma, yeni yazmanın değerlendirilmesi konusuna önemli bir katkı sunmaktadır.

\footnotetext{
Saydığımız bu çalışmalarda yazma için verilen sayfa numaraları farklılık gösterir: Azmun, Hacıyev ve Serrafî et al. (1) rakamı ile; Ekici ve Asker (1b) ile; Shahgoli et al., Quliyev ve Tulu (1a) ile başlamıştır. Rafraf'ın çalışmasında sayfa numarası kullanılmayıp metnin bölümleri dikkate alınmıştır. Geniş tahliller içeren Rzasoy'un eserinde ise transkripsiyon için Hacıyev kaynak alınmıştır. Biz bu çalışmada yazmanın ilk sayfasını $1 \mathrm{~b}$ olarak kabul etmekteyiz.

2 Azmun'un bu çalışmasının bir kısmı yayınlanmıştır (2020). Ayrıca Sertkaya ve Uzuntaş yazmaya dair araştırma ve incelemelerini bir kitapta toplamıştır (2020). T. Kocaoğlu'nun transliterasyon disiplinini önceleyen yeni bir çalışma hazırlığında olduğu bilinmektedir.
} 


\section{ग(৫)}

Bazı neşirlerde bu yeni keşiften "üçüncü nüsha" diye bahsedilmiş olsa da, nüsha kelimesinin işaret ettiği "tıpkısının aynısı olma" durumu Dede Korkut Kitabı'nın bilinen üç yazması için de söz konusu değildir (Sertkaya, 2019a). ${ }^{3}$ Üçüncü yazma ise, elimizdeki yazmalar içinde kuruluş ve muhteva bakımından en farklı olandır.

Yeni yazmanın isimlendirilmesi konusunda henüz tam bir birlik sağlanmış değildir. Saydığımız bu yayınlarda Türkmen Sahra tercihi önde görünmektedir. Ancak bilim dünyasında Günbed tercihi de geniş kabul görmüştür. ${ }^{4}$ İran'ın Türkmen Sahra bölgesinde, Gülistan vilayetine bağlı bir şehir olan Günbed-i Kâvus, hâlen yazmanın bulunduğu yerdir ve bu isim ona nispet edilmektedir. Türkmen Sahra ise bu şehrin bulunduğu coğrafi bölgenin adı olarak daha geniş bir çerçeve sunmaktadır.

Günbed yazması, soylama ağırlıklı bir metindir. Dresden ve Vatikan yazmaları gibi boy'lar hâlinde düzenlenmiş olmayan yazma, bu hâliyle upuzun bir mukaddimeyi veya bir soylama seçkisini andırmaktadır. Yazmadaki soylamalar birbirinden bağımsız olarak sıralanmıştır ve bir bütünlük oluşturmazlar. Toplam 61 sayfadan oluşan yazma, 25 bölüme ayrılmıştır ve genel kanaate göre 24 soylama ile bir boy içermektedir. Ancak metnin bir boy içerip içermediği, soylama sayısının kaç olduğu gibi hususlar tartışmalıdır. ${ }^{5}$ Bu yüzden yazmanın, soylama ve boy kavramlarının sınırlarını sorgulatan bir metin olduğunu söyleyebiliriz.

3 Ercilasun (2019) ve Özçelik'e (2019) göre bu yazma, Ankara'da bulunan yazmadan dolayı 4. nüsha sayılmalıdır. Ankara nüshası Sertkaya’ya göre bir varyanttır. (2019a). Özçelik, ayrıca Dede Korkut Oğuznâmeleri'nin sayısının 13'e çıktığını ifade etmektedir (2020: 7).

4 Ercilasun (2019), Özçelik (2019) ve Sertkaya, Günbed adını desteklemektedir. Türk Dili Derneği ile Isparta Süleyman Demirel Üniversitesi'nin ortaklaşa düzenledikleri 11-13 Haziran 2020 tarihli Dede Korkut Bilgi Şöleni ve Deli Dönmez'e Ad Verme Çalıştayı'nın üçüncü gününde, çalıştayın en önemli konusu olarak yeni yazmanın isminin ne olması gerektiği hususu tartışılmıştır. Bu tartışmalarda Türkmen Sahra ve Günbed adları öne çıkmış, diğer isimler elenmiştir. Günbed ismine en önemli eleştiri, Kocaoğlu ve Serrafî et al.'in de dile getirdiği, bu şehrin resmî adının Gonbad-i Kâvus olması şeklindedir.

5 Bu hususlar, Deli Dönmez'e Ad Verme Çalıştayı'nda tartışılmış, sadece yazmanın kesin olarak “iki hikâye içerdiği” üzerinde uzlaşıya varılabilmiştir. Bu durumda 17. soylamada anlatılan hikâyeler de bir anma veya temas olarak kabul edilmiş olmaktadır. Bu hikâyelerden yuvarlanan taş anlatısı, Salur Kazan'ın ejderhayı yenmesi kadar başat bir kahramanlığını anlatır. 


\section{Ј(৫)}

Yazmanın 38. ve 39. sayfalarında yer alan ve bizim bu çalışmada ele alacağımız soylama, yeni yazmanın en dikkat çekici kısımlarından birini oluşturur. Bu soylama üzerine birkaç makale yazılmış, soylamanın mitolojik çözümlemesi ise Rzasoy tarafından ortaya konulmuştur (2020: 260-296). Buruldum-ise saraldum-ise sözleriyle başlayan ve yapılan çalışmalarda 17 ile numaralanan bu soylama, bir destan kahramanı olarak Kazan'1 tanımlar ve kahramanlıklarını çerçeveler. Kazan'la ilgili bütün destanlar içinde bir tanıtma metni gibi duran bu soylama, her şeyden önemlisi Kazan'ın ad kazandığı soylama'dır ve bu yönüyle Kazan hakkındaki en önemli metinlerden biridir (Haznedaroğlu, 2020a). Soylamadaki parçaları bağlayan Gazan-idüm redifi ise doğrudan Dresden yazmasındaki ve Topkapı Oğuznâmesi'ndeki Kazan er-idüm ile Kazan-idüm redifli soylamaları akla getirmektedir.

Şiirsel ve yer yer mizahi bir üslup taşıyan soylamanın ilk bölümü "bulut, çiskin ve duman" üzerine bir teşbih ile başlamıştır. Bu başlangıcı nasıl değerlendirmemiz gerektiği, bu çalışma boyunca cevaplamaya çalışacağımız sorudur. Ilk bakışta "bulut, çiskin ve duman olmak", lirik çağrışımlar doğuran bir ifade olarak Dresden ve Vatikan yazmalarındaki Kazan karakterini tarif eden anlatımlardan farklı görülebilir. İfadeler bir tahavvül olarak değerlendirilmeye de uygun bir zemindedir. Ancak metnin bağlamının anlaşılması, bu sözleri Kazan'ı betimleyen bir kalıp olarak bir yere oturtmamızı sağlayacaktır. Çalışmamızda ilk yapacağımız, bu soylama başlangıcını diğer soylama başlangıçlarıyla karşılaştırmaktır. Metnin okunuşu ve anlamlandırılışı, bu bölümü takip edecektir.

Soylamanın ilk kelimeleri farklı şekilde okunmakta ve yorumlanmaktadır. Bu farklı yorumları metnin bağlamına ve Dede Korkut Kitabı'nın anlam dünyasına göre ele alacağız. Bizim geliştirdiğimiz yorum ise mevcut yorumlardan tamamen farklıdır. Bu yorumu temellendirmek için öncelikle kelimelerin etimolojik incelemesini yapacak, ardından da mitolojik arka planını anlamaya çalışacağız.

Korku, güç ve öfke arasındaki ilişkiler, epik metinlerin anlatım hususları ve bulut'un kutsal bir motif olarak taşıdığı anlamlar, kahramanın bir niteleyicisi olarak bulutun temsil çerçevesini belirlememizde aydınlatıcı olacaktır. Kazan'ın Dede Korkut Kitabi'nda ve Topkapı Oğuznâmesi'nde bulut ile vasfediliyor olması ise, bu metni tahlil etmemiz için elimizdeki en önemli karşılaştırma unsurudur. 


\section{1)}

\section{A. Soylama Başlangıcının Yazmadaki Diğer Soylamalarla Karşılaştırılması}

17. soylamayı yazmadaki diğer soylamalarla karşılaştırdığımızda birkaç husus öne çıkmaktadır.

\section{Soylamanın Anlatı İçermesi}

Dede Korkut boylarının içinde, çeşitli olaylara telmih yapan, hatırlatmada bulunan soylamalar oldukça fazladır. Birçok soylama, içinde yer aldığı hikâyenin olay örgüsüne dâhil olmuş, hikâyeye ayrıntı kazandırmıştır. Yeni bulunan yazma ise, hikâye açısından öncekiler kadar zengin değildir. Eserin sonunda yer alan ve vak'a içeriği çok geniş olmayan ejderha konulu boydan ayrı olarak yeni yazmada anlatı içeren iki soylama vardır. Bunlardan biri 17. soylama, diğeri Kars Kalesi'nin alınması ile ilgili olan kısımdır.

Kars Kalesi ile ilgili olan kısım, ilk durumdan son duruma doğru bir akış, yani bir anlatı ihtiva eder. Bu sebeple Azmun (2019) ve Sertkaya (2019b), bu metni boy olarak değerlendirir. Güvenmedüm sözüyle sonlanan bu anlatının bir kısmının eşmetinleri Dresden yazması ve Topkapı Oğuznâmesi'nde birer soylama olarak bulunmaktadır. Ayrıca Kazan dilinden bir aktarım olmakla bu metin Dede Korkut Kitabı'ndaki boy yapılarından farklıdır. ${ }^{6}$

17. soylama vak'a içeriği yönüyle Günbed yazmasının en çok gönderme içeren kısmıdır. Bu sebeple bu metnin de boy sayılıp sayılmayacağı tartışılmıştır. Burada sırasıyla Salur Kazan'ın “yuvarlanan taşı tutması, Ala Demür Kâfir Han'dan gelen kazanı kaldırması, katı yayı çekmesi, şişi ayă̆ıyla yere perçinlemesi” ile ilgili kahramanlıkları ve bunlarla birlikte ad kazanması, vekilliği elde etmesi ve padişah kızını ödül alması anlatılmaktadır (Bk. Haznedaroğlu, 2020b). Bu yüzden ele alacağımız soylama başlangıcı, Kazan hakkındaki bu anlatılara bizi hazırlayacak bir zemin kurar.

\section{Soylamanın Göksel Varlıklara ve Dağlara Dair Sözlerle Başlaması}

Ele aldığımız soylama girişii, "bulut, çiskin ve duman" olmaya dair bir tablo içermektedir. Soylamanın bu şekilde gökyüzüne temas eden bir girişle başlaması,

\footnotetext{
- Bu metnin on min yagı geldügini éşidende diye başlayan on satırlık bir kısmını Uçar, "bir soylama" başlığıyla ele almış ve eşmetinlerle karşılaştırmıştır (2020: 213). Söz konusu anlatının tamamı ise 50 satırdan oluşmaktadır.
} 


\section{$\mathrm{J}(\mathrm{O})$}

diğer soylamalarla karşılaştırıldığında genel bir eğilim olarak belirir. Nitekim eserdeki 23 soylamadan 15'i, "gökyüzüne, buluta, aya ve güneşe dair" sözlerle başlamaktadır. Bulutların hâllerine, sis ve dumana dair tasvirler ise 7 soylamanın ilk sözleri olmuştur. 17. soylamanın da "yağmurlu, dumanlı havaya dair" temas içermesi, eserin genel havasıyla bu açıdan uyumludur ve bizi aslında anlatıların kaynağı olan coğrafyanın fizikî bilgisine de taşır.

Gökyüzünün varlıklarını ve hallerini anış, eski dil yadigârlarımız paralelinde düşündüğümüzde anlamlıdır. Orhun kitabelerinde insan gök ile yer arasında tanımlanmıştır: üze kök tegri asra yağız yir kılındukda ikin ara kişi oğh kılınmış (Köl Tigin, Doğu 1). Ögel, kitabedeki bu ifadeyi, "gök + yer + insan" üçlüsünün yaratılışta birlikte göründüğüne bir işaret olarak almaktadır (2016: 185).

Soylamaların gökyüzü varlıklarından söz ederek başlaması, göksel olanla kutsal olanın birliği hakkında fikir vericidir. Sözü özellikle gökyüzü ile açmak, insanın başını göğe kaldırmasıdır. Başını göğe kaldırmanın şüphesiz fiziksel bir etkisi de vardır. ${ }^{7}$ Başını kaldıran insan, yukarısı ile, göksel olanla bütünleşmektedir. Yukarılara dair bu hatırlatma, insanı epik metnin ihtişamına hazırlayan bir işlev görür ve insanın göğün altındaki bulunuşuyla ilgili büyük hikâyeye bir gönderme içerir. Bu şekilde birçok soylama, açılışını en geniş çerçeveden yapmakta, göğü andıktan sonra yere inerek doğaya ve insana yönelmektedir.

Gökten ve dağlardan misaller vermenin bir yönü düzenliliğe dair vurgu olarak okunabilir. Dağları, ırmakları anıp alpların özelliklerini saymak soylamalarda sık rastlanan bir yapıdır. Meçhul anlatıcı çok zaman doğadan örnekler vererek merd igidler için de doğadaki kanunlar gibi değişmez kanunlar olduğunu bu şekilde hatırlatır. Gök varlıkları geleneğin insanlardan talep ettiği bir sabitliktedir, değişmezdir. Dolayısıyla soylamalar alp igidliğin ilkelerini sıralayan bir hitabe metni olarak değerlendirilebilir.

Rzasoy ilk soylamada geçen Dedem Korkud kırk şakirde kll nasihat (G.2a/3) sözüne vurgu yapmakta ve eseri bu 40 şakird için hazırlanmış bir talim, tedris ve telkin metni olarak değerlendirmektedir. Hedef 40 günlük keçid merasiminden

Yukarıya bakmanın bir fark edişle birlikte sunulduğu şu tablo ilginç bir ayrıntıdır: Begil yokarı bakdı. Gök ırak yir katı didi. Oğlancuğu yanına getürüp soylamış, görelim hanum ne soylamış. (D.123b/10) 


\section{0}

geçen 40 şakirde er igid / mert igid / alp igid olmayı ihata eden bilgileri benimsetmektir (2020: 84). Bu şüphesiz çok önemli bir dikkattir.

17. soylamanın bu şekilde başlamasını hem bir yüceleri anma, hem de bir yiğitlik vurgusu olarak alabiliriz. Yiğitliğin örnek ismi Kazan ile bulut arasında bir benzetim yapılmakta ve bu bir şarta bağlanmaktadır. Bu şart ilişkisinin ne olduğunu sormalıyız.

\section{Soylamanın Belli Bir Ritim ve Paralellikle İlerlemesi}

Soylamalarda genel olarak başlangıçta oluşturulan cümle yapısı, soylamanın bütününde devam ettirilmekte, belli kelimeler veya kalıplar tekrar edilerek bir paralellik oluşturulmaktadır. Metne dinamik bir üslup katan bu paralel ifadeler, tekrarlar ve leff ü neşirler, sözlü gelenekten aktarılan metnin şiirsel yapısını göstermektedir.

17. soylamada da paralel bir akış söz konusudur. Bu soylamada paralelliği sağlayan unsurlar öncelikle Gazan-idüm redifi ve onun önünde gelen sıfat-fiil unsurudur. Metin, ... duman olan Gazan idim /... son somuran Gazan idüm / ... sahlayan Gazan idüm şeklindeki bağlantı ifadeleriyle ilerlemektedir. Metnin devamında Kazan'ın gösterdiği kahramanlıklara karşılık elde ettiği mükâfatlar da aynı paralellikte sıralanmıştır: ad gazanan Gazan idüm /... vekillukı alan Gazan idüm /... cüldü kapan Gazan idüm. Gazan-idüm redifi metni 6 kısma bölmektedir.

Metinde paralellik içeren bir husus da altı degül altmış gibi eşya tarifleri ve rekabet unsuru olarak İç Oğuz’un Dış Oğuz'un beylerinin anılmasıdır.

Metin yer yer 8'li hece ölçüsüyle uyum gösterir. Ufak bir müdahaleyle bu uyumu daha da arttırmak mümkündür (Buruldumsa saraldımsa / gök yüzinde bulut oldum ...).

Soylamanın giriş cümlesi, Salur Kazan'ın kendisini tanımlaması şeklinde bir kurgu içermektedir ve bu kurgu soylama boyunca devam etmiş, anlatılar bu kurgu içine yerleştirilmiştir. Önceki yazmalarda ve Topkapı Oğuznâmesi’nde de

8 Kara kazan altı degül almış batman, şiş(ler) ise altı değil yeddi dutum olarak belirtilmesine rağmen katı yayla ilgili altı degül ibaresi metinde geçmemiştir. Ancak Kazan'ın çektiği yayla ilgili yaptığımız araştırmadan, burada bu ifadenin sehven atlandığı sonucuna ulaşmaktayız. Eski Türk yaylarında kabzada altı boynuz şeridi kullanılabildiğine ilişkin bilgiler, Dede Korkut Bilgi Şöleni’nde bildiri olarak sunulmuş, bildiri kitabına sehven alınmamıştır. 


\section{1)}

benzer şekilde karşımıza çıkmış olan bu tanımlama kalıbının Kazan için kullanılmış olması altı çizilecek husustur.

\section{Soylamanın Salur Kazan Dilinden Olması}

Dede Korkut Kitabı'nda Kazan Han'ın ağzından söyleyiş içeren soylamalar fazladır. Dresden yazmasında boylar içinde yer alan soylamaların büyük bir kısmının söyleyeni Salur Kazan'dır. Günbed yazmasında da Kars Kalesi'nin alınması ile ilgili bölüm, Kayser Salur ayası, dumanlı dag börisi şeklindeki takdim sözleriyle başlar ve Gazan der diyerek sözü Kazan'a devreder (G.25a/7). Böylece bu anlatı da Kazan dilinden bir anlatımla karşımıza gelmiş olur. 65 satırdan oluşan Topkapı Oğuznâmesi'nin de son 10 satırı yine Salur Kazan dilindendir. Aktarımın geçmiş zamanlı olarak verilmesi buradaki soylamaların kahramanın ölümü ardından yapılan bir anış olduğunu düşündürebilir. 17. soylamada da benzer bir durum söz konusudur. Bu durum, destanın icra edildiği zaman ve ortam hakkında, anlatıcı ve dinleyici ilişkisi konusunda da önemli sorular sordurmalıdır (Bk. Aça, 2007). Kahramanın "ben" diliyle anılışını, destan anlatıcılarının kahramanı içselleştirmesi olarak da okumak mümkündür.

17. soylamanın ben diliyle başlaması, metnin soylamalar içinde hemen fark edilmesini sağlamaktadır. Bu soylamayı takip eden soylama da ben diliyle başlamıştır ancak söyleyeni Dedem'dir (Dedem der). Kazan ve Dedem Korkut bu yazmada karşımıza çıkan iki anlatıcı olmuştur.

\section{B. Soylama Girişinin Okunuşu ve Anlamlandırılması}

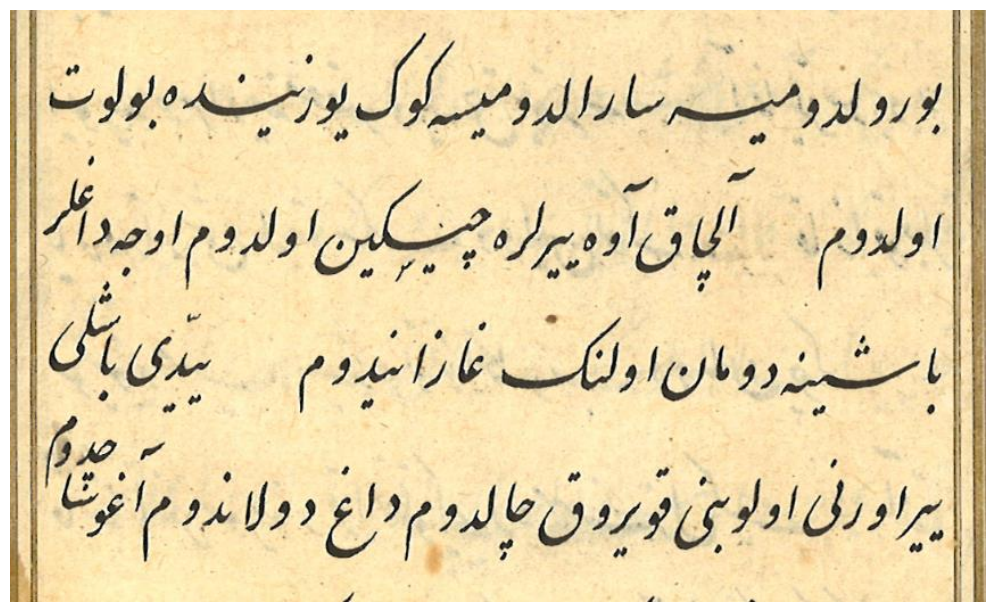

Resim I, 17. Soylamanın Başlangıç Bölümü (20a) 


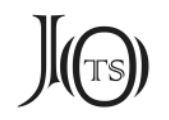

Günbed yazmasındaki 17. soylamanın başlangıç bölümünün transliterasyonu şu şekildedir:

BWRWLDWMYSH ŚARALDWMYSH KWK YWZYNDH BWLWT

AWLDWM ALÇAQ AWH YYRLRH ÇYSKYN AWLDWM AWCH DAǴLR

BAŞYNH DWMAN AWLNK ĠAZANYDWM

Metnin okunuşunu mevcut çalışmaları da dikkate alarak şu şekilde tespit edebiliriz:

Buruldum-ise, saraldum-ise, gök yüzinde bulut oldum.

Alçak ava yérlere çiskin oldum

Uca daglar başına duman olan Gazan-idüm. (G.20a/1-3)

Üst kısmının başlık için boş bırakıldı̆̆ı tahmin edilen bu metnin okunuşundaki en temel farklılık, ilk kelimenin okunuşunda görülmektedir. BWRWLDWM şeklinde yazılan bu kelimeyi buruldum veya bürüldüm olarak okumak mümkündür ve çalışmalar bu konuda ihtilaflıdır. İnce sıralı okuyuşu tercih edenler çoğunluktadır.

Bu temel farklılık dışında bir önemli farklılık Quliyev'in SARALDWM yazılışlı kelimeyi sarıldım şeklinde okumasıdır.

Shahgoli ve ekibinin olan kelimesinin sonundaki nun ve kef harflerini $\eta$ şeklinde değil de $n g$ şeklinde okuması ve ikinci -ise bağlacını ünlü uyumuna göre -ısa okumasını da biçimsel bir farklılık olarak sayabiliriz.

\section{Bürüldüm Şeklinde Okuyanlar}

Ekici (2019: 105) ve Shahgoli et al. (2019: 217), bürüldüm-ise saraldım-ise şeklindeki ince sıralı okuyuşu tercih etmiştir. Metnin Asker (2019: 87) ile Serrafî et al. (2019: 60) tarafından hazırlanan Azerbaycan neşirlerinde ve Hacıyev'in şerhli makalesinde (2019: 46) ve Rzasoy'un açıklamalarında da (2020: 261) kelime yine ince sıralı olarak okunmuştur.

Bu şekildeki okuyuş, iki farklı yorumlayışın zemini olmaktadır: 


\section{ग(৫)}

\section{a) Bunalmak Yorumu}

Ekici, soylamanın ilk sözlerini günümüz Türkçesine 'bunaldığımda sarardığımda' şeklinde çevirmiştir (2019: 190). Bu anlamlandırmada Ekici, sararmak'tan ve belki bürülme'nin 'büzüşmek' şeklindeki dolaylı anlamından yola çıkmış olmalıdır. Bu durumda bürülme ve saralma 'güçten düşme, zayıf kalma' anlamında düşünülmüştür. Kazan'ın bunaldığında neden bulut olduğunun açıklaması yapılmamış olsa da, bulutların bir hüzün simgesi, efkârlanma ifadesi olarak düşünüldüğü sezilmektedir.

Kanaatimizce bunalma, bir destan kahramanının kendisini överken anacağı bir kelime olmaya uzaktır, çünkü acizlik bildirmektedir. Her şeyden önce bir destan metninin muktedir edasına bu kelime yakışmayacaktır. Bunalma'yı Dede Korkut metinlerinde bir yenilgi ve perişanlık hâli olarak ve özellikle karşı tarafın küçümsendiği ifadelerde görmekteyiz: ${ }^{9}$

Han kızı halaluyı tanımayan gözüy ulmış, buyalmışsın saya ne olmış? (D.76b/9-10)

Bu ismarladuğun nesnedur, n'oldun böyle buyaldun? (D.46a/7).

Kara başı buyaldı buylı oldı. Hemân döndi kal'aya kaçdı. (D.107/1)

Er buyaldırdum buşkunumda ben Kazan. (T.0.3/55)

Kara başların buylu eden (......) Ulaş oğlu Salur Kazan (T.0. 2/33)

Zayıflığını söylemenin bir kahramanca ne kadar zor olduğuna Dede Korkut kahramanlarından Begil ve Kanturalı örnekleri verilebilir. Attan düşüp ayağını kıran Begil bunu herkesten saklamıs, hatununa bile beş gün sonra diyebilmiştir (D.123a). Kanturalı, hayatını kurtaran Selcen Hatun'u Kanturalı zebun oldu diyerek kendisinin âciz hâlini Oğuz'a anlatabilir diye, bir eziklik duygusuyla öldürmek istemiştir. Kazan da, ejderhanın heybetinden pusaran (D.141b/7), bulaşan ve kana dönen (G.29a/12) gözüne nâmert demiş bir kahramandır. O yüzden bu çeviri, destan diliyle uyumsuzluk gösterir demekte haklı oluruz.

Sıkıntının ("bungunluğun") dumana, yele benzetilmesi haklı bir yorum olabilir. Kâşgarlı Mahmud'un mụ kelimesiyle ilişkili olarak aktardığı şu söz de bulutu gamla eşleştirir: Erke mụ tegir, tag senirine yel tegir. "Adama sıkıntı değer,

\footnotetext{
9 Dış Oğuz'un Iç̧ Oğuz’a âsi olduğu boyda Kazan için kara başı buylu oldu (148b/1) ifadesi geçmektedir. Ancak burada bu ifade bir sınama için kullanılmıştır. Beyrek için de aynı hikâyede Kara kana bulaşdı buglu oldu (151a/12) denilirken Beyrek ölmüştür.
} 


\section{Ј(@)}

dağın zirvesine yel değer." (Ercilasun \& Akkoyunlu, 2014: 493). Ancak kahraman bunalan değil bunaltan olmalıdır. Bunalmak, bir övünme biçimi olmaya uzaktır.

\section{b) Bürünmek Yorumu}

Bürülmek okuyuşunu Shahgoli et. al (2019: 237) ve Serrafi et. al. (2019: 194) sözlükçede "bürünmek" olarak açıklamıştır. İlk kelimedeki \{-l\} eki, dönüşlülük eki olan \{-n\} fonksiyonunda olabildiği için, ifadenin büründüm-ise sarındım-ise şeklinde alınması mümkündür ve doğrusu bulut, çiskin ve duman olmak bir tahavvül olarak değerlendirilmeye uygun görünmektedir. Rzasoy da metne dair açıklamasını "çevrilme" (dönüşüm) kavramı üzerine kurmuş, bu dönüşümün mitolojik çözümlemesini yapmıştır (2020: 260-296).

Rzasoy'a göre Kazan'in hidroçevrilmesi su $\rightarrow$ duman $\rightarrow$ bulut $\rightarrow$ çiskin şeklinde bir sırayla ilerler: Evvelce dağlar başında duman idim. Sonra gökyüzünde buluta çevrildim. Daha sonra yere inip ovalikta çiskine çevrildim (2020: 262).

Şekil değiștirme mitik anlatıların önemli bir motifidir ve tanrısallıkla ilişkilidir. Şekil değiştirmekle ilgili tespit edilen ilk Türkçe metin de Burkancıllk muhitinde yazılan bir şiirdir. Bu şiirde "bir şekilden başka bir şekle girme" anlamında kubulmak (Moğolcada hubilgan) kelimesi geçmektedir (Arat, 1991: 342343). Uygur harfleriyle yazılan Mîrac-nâme eserinde Cebrâyil öz sûretiga kopuldı. Altı yüz kanatlı kuş old, şeklinde kullanılmış olan (Sertkaya, 1968) kubulmak kelimesi, "kabuk değiştirmek" anlamıla bürünüp sarınmaya paralel değerlendirilebilecek bir ifadedir. Nitekim "don değiştirme” başlı̆̆ında Ögel, kabulma ile birlikte giyimini giyme deyimine de yer vermektedir (2014: 173). Don değiştirme, halk anlatılarında "şekil değiştirme" için kullanılan genel bir ifadedir. Bu motif, özellikle güvercin, kırlangıç gibi kuşlara, geyiğe ve ejderhaya dönüşmek şeklinde karşımıza çıkar. Soylamanın devamında da Kazan'ın kendisini “ejderha olmuş” gibi anlattı̆̆g görülecektir: Yeddi başl yer evreni oluban...

Rzasoy'un deyimiyle "birinci bendde öz hidroecdadlarına çevrilen Qazan" ikinci bentte de yeddi başlı ejderhaya $m ı$ çevrilmektedir? Bizce Kazan, ejderhayı yenip postunu giyinmesi olayına mizahi bir gönderme yapmaktadır. Bu olay, yeni nüshanın en önemli hikâyesidir ve bu hikâyede de aynı mizah sezilebilir. Kazan'ın ejderha öldürüp postunu giyindiğini bilmeyen Sadık Türk "adam nasıl 
ejderha olur" demeden kaygıya düşmüştür: (Gazan) ejdehâ olubdur, bizi hamı utar (G.30b/10).

Benzer şekilde Kazan'ın bulut olmaktan kastı da tahavvül olmasa gerektir. Tahavvül, kanaatimizce bu epik metnin doğasına yabancıdır. ${ }^{10}$

Dede Korkut Kitabı'nda şekil değiştirme motifini sadece Azrail şahsında görmekteyiz. Deli Dumrul, kılıcını sıyırıp kendisine hamle kılacakken Azrail bir güvercine dönüşüp uçmuştur. Deli Dumrul'un bu mucize karşısındaki tavrı ise elin eline vurup kas kas gülmek şeklindedir:

Yiğitlerüm! Azrayıl'un gözüni eyle korhutdum ki, gin kapıyı kodı, dar bacadan kaçdı. Çünki menüm elümden göğercin gibi kuş oldı uçdı. Mere ben anı kor mıyam doğana aldurmayınca! (D.81b/8)

Deli Dumrul'un bu sözü, Dede Korkut Kitabı'nın dünyasında şekil değiştirmeye karşı genel bir kanaati yansıtabilir. Şekil değiştirmek kutsal ile ilişkilidir, keramet ve büyüdür. Savaş hilelerini bile (gece baskını, uyuyorken saldırma) erliğe uygun görmeyen kahramanlar, böyle bir kudrete ihtiyaç duymazlar. Hatta bu kudrete "deli" sıfatıyla meydan okur, şekil değiş̧irmeyi acizlik olarak değerlendirebilirler. ${ }^{11}$ Kahramanların gücünün fizikî varlıklarına dayandığı düşüncesi, sürekli bedensel kudretleriyle övülmeleriyle de vurgulanmaktadır.

10 Kelime bürüldüm okunduğunda en makul çözüm "tahavvül” olduğu için bu kısmı açmak istemiştim. Aylar sonra bu makalenin son teslimine günler kala Rzasoy'un bu konuyu detaylıca ele aldığını görmüş oldum. Rzasoy "transformiya, çevrilme" ile ilgili oldukça değerli bilgiler vermekte ve dikkatli hükümler sıralamaktadır. Bu hükümlerden birkaçı şu şekildedir (Türkiye Türkçesine yaklaştırarak): Kazan'in çevrilmeleri mitik düşünce ile ilişkilidir. Bunlar canlı bir varlı olan Kazan'in öz cildini, zahiri görkemini, ipostasını değiştirme kabiliyeti; başka bir deyişle, diğer bir varliğa, bitkiye, eşyaya, taşa vs. çevrilme imkânını yansıtır. Kazan çevrilmeler zamanı birden çok görünüşte ortaya çıkar. Ancak bu değişiklik geçici olup Kazan'in asl mahiyetini değiştirmemektedir (...) Kazan'in çevrilmeleri ritüelde ölerek başka nesneye çevrilmesidir. (...) Kazan'ın çevrilmeleri totem / ongunlarla bağl çevrilmelerdir. Bu ongunlar Kazan'in ecdad şeceresi ile bağhl "kökleri", akrabaları olduğu için o, muhtelif şekillere girebilir. Bu cihetten Kazan'ın çevrilmeleri ongunun, tanrinin gücü, yani onların sayesinde olur (2020: 268-269). Ayrıca Rzasoy Kazımoğlu'ndan şu sözü aktarır: Folklordaki cildden cilde girmek sujetlerinin en geniş yayılanlarından biri sihirli suret (don) motifi ile bağlıdır. Bu suret adi insanlara değil sihirli kuvvelere bağlıdr. (2020: 272).

11 Kazan Bey'in öldürdüğ̈̈ ejderhanın postunu giyinmesi veya Bamsı Beyrek'in ozan kılığına girmesi, fizikötesi bir durum olmadığından şekil değiştirme sayılamaz; giyim-kuşam, karşı tarafı şaşırtmak için kullanılan bir araç, bir mizah unsurudur. 
Rzasoy'un işaret ettiği üzere suyun, dumanın, bulutun ve ejderhanın mitolojik anlamları göz ardı edilmemelidir ancak bu anlamlar teşbih ile de açıklanabilir. Kazan şahsında bir yiğidin övgüsü bu benzetimlerle ve göndermelerle yapılmaktadır.

\section{Buruldum Şeklinde Okuyanlar}

Azmun (2019: 52), Quliyev (2020: 60), Rafraf (2020: 46) ve Tulu (2020: 340) ilk kelimeyi kalın sıralı okumuştur. Bu okumada daha çok bulut'un hal değişmelerine dayanan ve etimolojik temeller arayan yorumlar söz konusudur.

\section{a) Hoş Kokulu Sis Yorumu}

Azmun, bu soylamanın ilk kelimelerini buruldum-ise saraldum-ise şeklinde okumuş ve metnin çevirisinde bir ilavede bulunmamıştır (2019: 52, 81). Fakat Azmun'un yeni yazmadaki iki anlatıyla beraber bu soylamayı İngilizceye çevirdiği çalışmasında burulmayı 'hoş kokulu bir sise dönüşmek' (to take the form of a fragnant mist) anlamında aldığı görülmektedir:

If I took the form of a fragrant mist and turned yellow, it was by becoming a cloud in the sky. On the lower slopes of the mountain I became a drizzle; I was Gazan who became mist on the summit of the high mountains. (2020: 25).

Azmun'un burada burulma'nın 'kokmak' anlamindan ve bulut kelimesiyle akrabalığından hareket ettiğini düşünmek mümkündür. Nitekim Ercilasun da, burul- için verilen 'buram buram yükselmek' anlamının gökte bulut olmak için daha uygun olacağını söylemiştir (2019: 21). Azmun'un yorumlayışına göre bulut ve dağlar bir kutsallık sembolü olarak işlenmektedir.

Kâşgarlı Mahmud'un sözlüğünde, yıpar burdı sözüne 'misk kokusu yayılması'; su burdı sözüne de 'çevreye güzel bir kokunun yayılması veya bir şeyin buharının yükselmesi' anlamını verdiği görülür (Ercilasun \& Akkoyunlu, 2014: 234). Arat da bura tur- fiilini 'güzel koku yaymak' (1968: 436), Clauson, bur- fiilini 'kokmak' anlamiyla almaktadır (1972: 355a). Bur- kelimesinin burun kelimesiyle de bağ1 düşünülmektedir (Eren, 1999: 664). Farsçadaki bûy > bû kelimesinin de 'koku' anlamına geliyor olması ilginç bir tesadüftür.

Bur- fiilinin bulut ile etimolojik ilişkisi, sözlük çalışmalarında açıkça görülmektedir. Clauson, 'buhar' anlamındaki bu kelimesine buğ’un (buğu) eski 


\section{ग(৫)}

formu olarak yer vermiştir (1972: 292a). Bu-s pu-s ise 'duman, sis' anlamindadır (1972: 370b). Buğ gibi bus < bus; bull-t > bulu-t < bu-lı-t gibi şekiller bu pu ile bağlantılı düşünülmektedir. Tekin'in bulut kelimesinin sonundaki /t/ ünsüzünü çokluk eki olarak değerlendirdiğini de bu etimolojik örüntüye eklersek bulu-t 'gökyüzündeki su / buz zerreleri' demek olur ve bu köküne daha da yaklaşılmış olunur.

Nitekim H. Şirin de, bulut kelimesini detaylı olarak incelediği makalesinde bu kelimenin bū 'buhar, buğu' kelimesinden ayrı incelenemeyeceğini söylemektedir (2017: 382). Ona göre, Eski Türkçedeki bû 'buğu' adından bur-fiili türemiştir ve bu fiil 'buhar çıkmak' anlamındadır. Bulut'la ilişkili olan çig, tüpi, bug, bus, tuman gibi kelimeleri Türkçenin tengri kadar eski verileri olarak sayan Şirin, makalesinde ayrıca şu sonuçları sıralamıştır:

Etü. bug 'buhar; sis'; Etü. būs 'pus' (TTü., Kum., Nog. Şor. pus, Uyg. Tuv. bus vd.); Etü. bur'buhar çıkmak; koku çıkmak'; Kumukça bugak, Karaçay-Balkarca buvak 'kırağı'; Kzk., KKlp. buldır 'sisli, bulutlu', Krg. buldur 'puslu; bulutlu' vd. Bu türevlerin yanına Etü. buzun eklenmemesi için ileri derecede anlam değişmesi dışında bir sebep yoktur: buz (TTü., Az. Gag., Krm., Kum. buz, Tkm. būz, Yak. būs, mūs, Özb., Uyg. Kzk., Krg. muz vd.) (2017: 380)

Bütün bu etimolojik bağlantılardan hareketle, Kazan'ın burulup saralması, bulut olmaya ilişkin hâller olarak yorumlanmış olmaktadır. Zira saralma da bulutla ilişkili bir hâle atıf olarak değerlendirilmeye uygundur. Metnin başka bir yerinde bu kelime Ne çaklarda seher irte dan bulutı saralanda (G.24b/9) şeklinde, seher yelinde sallanan taze otlardan da bahseden bir sabah manzarası tasvirinde görülmektedir. Üç çalışma da sözlükçelerinde bu kelimeye 'sararmak' olarak yer vermiştir, ama sabah tasvirindeki sararmak, 'altın sarısı 1şıklara' bir göndermedir ve "sararıp solma" ile bir ilgisi yoktur. Sabahı tasvir eden saralma'ya dair güzel bir örnek Koblandı Destanı'nda görülebilir:

Tay sargayıp atkanda

Şolpan juldız batkanda (Kuanışbayeva, 1998: 146)

Azmun'un yapmış olduğu yorumlamaya göre saralma, doğmakta olan güneşin şavkını ifade eder ve soylamanın girişinde olumsuz çağrışımlardan uzak, mutluluk dolu bir tablo söz konusu olur. Sabah gün doğarken bitki ve çiçeklerin üzerinde beliren çiğ, etrafa yayılan taze kokular, altın sarısı 1şıklar bu mistik sahneyi tamamlayan unsurlardır. Böyle bir tabloda Kazan, mutluluğunu naif bir şekilde anlatmaya çalışmış olmalıdır. 
Evinin yağmalandığı boy'da Hak didârın görmişdür (D.24b/1) diyerek suyla söyleşmesini okuduğumuz Kazan'ın, bu kez kendisini bulut olarak tanımlaması, metnin lirik bir zeminde anlaşılmasını mümkün kılmaktadır. Bu yüzden Azmun'un burulma'yı ve saralma'yı olumlu olarak değerlendirişi, tutarlı bir yorum olarak görülebilir. Bu zengin çağrışımlı yorumda bizim şüphemiz, Kazan'ın bu ifadeye neden ihtiyaç duyduğunu sormak şeklinde ortaya çıkmaktadır. Bütün soylama boyunca bize ne kadar güçlü olduğunu, yer yer alaycı bir dil kullanarak anlatacak olan Kazan, neden en başta hoş kokulu bir sis'e dönüşmüş ve saralmış (sarı bir ışıkla parlamış) olarak karşımıza çıkmıştır? Epik metnin üslubundaki güçlülük vurgusu, bu naif ifadeyle ne şekilde beslenir?

Dağların ve bulutun kutsallıktan dolayı rahmetle ve huzurla yâd edilişi, soylama metninin havasıyla birlikte düşünülmelidir. Kazan güçlü, yırtıc1 (ejderha göndermesi), en çetin şartların üstesinden gelici, başarılamayanı başaran ve bunun ödüllerini toplayan bir kahraman olarak övünürken, en başta kendisini bulut, çiskin ve duman olarak övmüştür ve düğ̈̈m burada yatmaktadır.

\section{b) Kıvrılmak, Sarılmak Yorumu}

Quliyev de bu soylamanın ilk kelimelerini buruldum ise sarıldım ise olarak okumuş (2020: 60) ve kelimeleri yine "bulutun bir hâli" olarak değerlendirmiştir. Quliyev'e göre burulmak, bulutların hareketinin bir tarifidir. Bulutların burulması ile yağmurdan önce gökyüzünde bulutların kıvrımlar oluşturması, birbirine karışarak hareket etmesi anlaşılmalıdır.

Bu yorum için bur-fiilinin 'döndürülüp bükülmek, kıvrılmak' (Ayverdi, 2011: 429) anlamıyla düşünüldüğünü söyleyebiliriz. Burmak fiilinin bugün de yaygın olarak kullanılan anlamı 'çevirmek'tir (Tekin et al., 1998: 87). Buruk Azerbaycan Türkçesinde 'kıvrım' demektir (Seyidaliyev, 2007: 62). Burulmak 'buruk düşmek, kıvrılmak' anlamındadır. Yeni yazmada yayların kurulmasıyla ilgili boynuz ilen burulanda (G.4a/3) ifadesi geçmektedir ve bu da yayın kurulmadan önce dış kısmında olan boynuz aksamının yay kurulurken iç tarafa çevrilmiş olmasını ifade etse gerektir. ${ }^{12}$ Ayrıca okun düz şekilde (ki bu ses çıkarmakla da ilişkilidir) gitmesini ifade eden burulmayub dogrı çıan ok ötkünü (G.4a/4) ifadesi de vardır.

12 Bu konuda Hacıyev, Möhkem yayların teke buynuzundan düzeldilmesine işare edilir demektedir (2020: 15). 


\section{1)}

Bulutların burulması ilişkisinden hareketle olsa gerek hortum, kasırga gibi güçlü rüzgâr hareketleri ve sert doğa olayları için de bur- kökünden gelen kelimeler mevcuttur. Burulgan, bururgan, burutgan ve burlağan kelimeleri 'girdap, dönen su' anlamına gelen kelimelerden birkaçıdır (Öztürk, 2005: 202; Seyidaliyev, 2007: 62). Ayrıca ağızlarda burgaç kelimesi 'girdap' anlamında kullanılmaktadır. Anadolu'da kasırga ve hortumlara buruk, Kırgız Türkçesinde kar firtınasına burganak denilmektedir (Ögel, 2016: 398).

Quliyev'in burada SARALDWMYSH yazılışlı kelimeyi sarıldım ise olarak okuması da burulma'nın anlamıyla ilişkili bir tercih olmalıdır. Sarılmak 'bir şeyin etrafına dolanmak, bükülmek' (Axundov, 2006/4: 41b) anlamlarılla burulma'ya yakın bir anlamdadır ve bulut teması ile uyumludur. Böylece Kazan'in burulması da sarılması da bulut olmaya doğru bir dönüşüm, bir hâl değişimi olarak anılmış olmaktadır.

Burulup saralma'yı bulutla ilişkilendiren yorumlarda "yağdım ise yağmur oldum" demeye benzer bir şekilde ise bağlacı "hâl"i betimlemeye aracı olmakta ve Kazan'ın dönüşümü detaylandırılmaktadır.

\section{c) Bozulmak Saralmak Yorumu}

Rafraf da ilk kelimeyi kalın sıralı okumuştur, ancak dipnotta "Bir ihtimale göre bozuldum, bozardım" (2020: 46) kaydını düşmüştür. Metnin çağdaş Azerbaycan Türkçesine aktarımında yine bu ihtimali değerlendirmiştir: Burulub saralıb (bozarib saralı?) (2020: 79). Bozarmak, 'bulutun kararmas1, bozulması' olarak düşünülmeye uygundur ve bu kelimenin 12. soylamadaki busalk kelimesiyle ilişkisi ihtimal dâhilindedir: Kay busalık erdemidür... (G.16a/4).

Bir başka kalın sıralı okuma da Tulu'ya aittir. Tulu açıklamaya gitmeksizin ifadeyi şöyle nakleder: Buruldumsa / burundumsa / saraldımsa (2020:304).

Günlük kullanımda olan bir ifade olmadığından her araştırmacının bu kelimelere yaklaşımının farklı olduğu görülmektedir. Ancak genel olarak buluttaki hâl değişimleri yorumlara yön vermiştir. 


\section{Diğer İhtimaller}

Bur- fiiline dair yukarıda sayılan etimolojik bağlantılarla anlamlı olabilecek bir ifade, Altın Taycı destanında bulunmaktadır. Ancak burada, bulut olmanın sebebi yorgunluktur:

Aran çula ak kır at / Dönüp dolaşmakta

Tuzlu teri ak bulut olup/ Açık gökyüzüne dağılmaktadır

Köpürmüş teri gök bulut olup / Mavi açık göğe yükselmektedir (Dilek, 2018: 84'ten Yılmaz 2013: 169).

Köpüklü teri bulutla ilişkilendiren bu ifade, Kâşgarlı Mahmud'un sözlüğündeki ter burçaklandı sözünü hatıra getirecektir (Ercilasun \& Akkoyunlu, 2014: 602). Türkmencede de burçaklama 'terleme' anlamındadır (Tekin et al., 1998: 87). Böylece burulmak ve bulut arasındaki etimolojik ilişki daha karmaşık olmaktadır. Ancak elimizdeki metnin buradaki benzetimle bir paralelliği yoktur, buluta dönüşen Kazan'ın kendisidir.

Aslında yine iştikaktan yola çıkarak burulma'yı 'buruşmak' olarak değerlendirmek ve Kazan'ın yaşlanmasına yormak da mümkündür. ${ }^{13}$ Dahası, uçmak deyiminden hareketle bulut'u ölümün bir metaforu olarak değerlendirmek de imkân dâhilindedir. ${ }^{14}$ Kelimeyi bürünmek olarak alıp 'bulut kaplamak' anlamından hareketle başka bağlantılar kurmak bile mümkündür.

13 Ak saçlı kırışık tenli ihtiyarlığın buluta teşbih edilmesi anlamlı görülecektir. O zaman burulma ve saralma ten kırışmasının, zayıflamanın örtmeceli bir ifadesi olur. Böylece Kazan, yaşlansa da bir bulut gibi yükseldiğini söylemiştir şeklinde bir yorum yapılabilir. Nitekim 'yaşlanmak' Dede Korkut Kitabı'ına göre bir erdemdir: Yanakından akarursa baba yakşı (G.23a). Fakat metnin bağlamından dolayı bu yorum sadece bir yakıştırma olabilir.

14 Düşünürsek “ölüm” bu tabloya uyarlanabilir. Nitekim Tekin, Köl Tigin yazıtının kuzey doğu yüzündeki 3. cümleyi Köl tigin ö[zi?] kırk artuk[ı y]iti yaşınga bulıt bust[adı?] şeklinde okumuş ve busta- kelimesini sözlükçeye 'bağırmak, kükremek' anlamlarıyla almıştır (1968: 237, 322). Buna ilave olarak kendisine danıştığımız Sertkaya, "busta- fiilinin Hakas Türkçesinde pusta-şeklinde yaşadığı" bilgisini vermiştir. Şirin de bulut olma'nın ölüme dair bir metafor olabilmesi hakkında Yong-Song Li'nin okuyuşuna yer vermiştir: Li, Kül Tigin özi kırk artukı yiti yaşııı bult boltı “Kül Tigin'in kendisi kırk yedi yaşında bulut oldu (vefat etti)." olarak okuyup anlamlandırmıştır (2008: 214-215). Radloff Atlası'na dayanan bu düzeltme önerisi ilgi çekici ve düşündürücüdür" (2013: 374). Günbed yazmasının Kazan Bey'in ölümünü haber vererek bitmesi (Gazan kimi koçak igid dünyâdan geldi geçdi) ve ölen kişilerin ruhlarının "uçtuğunun" söylenmesi, "bulut ve ölüm" ilişkisi üzerine anlamlı bağlantılardır. Fakat bu soylama için ölüm metaforu da ancak edebî bir yakıştırma olabilir. 


\section{ग(৫)}

Her yorum da çeşitli dayanaklar bulabilir. Her ihtimalde de göze çarpan, güçlü bir müraât-ı nazîr (tenasüp) sanatı ile iştikak sanatı olacaktır. Kelimelerin akrabalığı ve birbiriyle doğrudan ilişkilendirilebilmesi, burulma kelimesini birçok açıdan değerlendirmeyi mümkün kılmaktadır. Burulmayı takip eden saralma da yine bulutla birlikte anılmış bir kelime olarak bu yorumlara kuvvet vermektedir. Oysa Kazan'ın burulma ve saralmasını fizikî bir hâl veya tahavvül olarak değil bir duygu durumu olarak düşünmek en kolayıdır.

Bizim çalışmamıza göre burulmak okuyuşu doğrudur. İkilemedeki ses uyumu da bu okuyuşu güzelleştirir. Fakat tahlil çalışmamızda burulma'nın bulut ile ilişkisini köken ilişkisi olarak düşünmek yerine duygu bağlantısı olarak almayı ve bulut'un hangi duyguya karşıllık olabileceğini düşünmeyi teklif ediyoruz. Buna göre burulup saralmak "kızgınlık, gazap" hâlini tarif eden, etimolojik kanıtları da olan bir ikilemedir. Bulut olmak da "gürlemek" ilişkisiyle bu kızgınlığın neticesi veya remzi olmaktadır. Bulutun fizikî halleri bu kelimelere yoracağımız anlam değildir, çünkü ise bağlacı burada bulut olmaya bir şart sunmakta, yani sebebi işaretlemektedir.

\section{Burulmak ve Saralmak}

Burulma, mecaz olarak "hoşnutsuzluk" anlamında kullanılan bir kelimedir. Sözlüklerde 'alınmak gücenmek' şeklinde mecaz anlamına rastlanabilen bu kelimenin ağızlarda 'darılmak, küsmek, somurtmak' anlamı bulunmaktadır (Güncel Türkçe Sözlük). Türkmence sözlükte bu kelime 'kapris yapmak, nazlanmak' olarak alınmıştır (Tekin et al., 1998: 88). Ege ağızlarında 'somurtma, yüzünü buruşturma' anlamında kullanılan kelime ise burutma'dır. Yüzünü buruşturma deyimi ile ilgisi açık olan bu ifadenin 'hoşnutsuzluk' anlamı, burkulma kelimesinde de sezilmektedir. Clauson'un burk- fiiline verdiği yüzi burkurdı örneğinde de bu anlam görülecektir (1972: 361b). Burkuldama'nın 'gürlemek, kızgın hâle gelmek' anlamını ise Arat nakletmektedir (1991: 342).

İkinci kelimemiz olan saralma, "sarı renk almak" anlamında olup (Axundov, 2006/4: 38b) Türkiye Türkçesine sararmak olarak ulaşmış kabul edilmektedir (DS: 601) Yeni yazma ile ilgili çalışmaların sözlükçelerine de bu şekilde "sararmak" olarak alınmıştır. 
Fakat buradaki saralma ile sararma gerçekte aynı kelimeler midir? Renk anlamı olan sarı + ar-mak > sargarmak > sararmak ile "çevirmek, dolanmak" anlamı olan sar-(l)-l-mak > sarllmak (Bk. Gülensoy, 2018: 598-599) kelimelerinin birbirine katıştırıldığını söyleyebiliriz.

Sarmak fiilinin "kızmak, çıkışmak, sertelmek, sert söz söylemek" anlamını Gülensoy aktarmaktadır (2020: 598). Kelimenin ağızlarda "köpek havlamak, saldırmak" (DS: 3547) anlamı da bulunmaktadır. Clauson benzer anlamları sars(bk. sarst-) maddesinde sıralamıştır. Sarst- fiilinin "kabalaşmak, sertleşmek, kaba bir dil kullanmak" anlamını vermekte, ayrıca "kaba, sert, haşin" anlamındaki sarsı için sarsıg söz, sarsığ gönüllü örneklerini kaydetmektedir (1972: 854b). "Sertleştirmek, kabalaştırmak" anlamını verdiği sarsıt- için ise "sert davranmak" anlamında $\mathrm{Ol}$ anı sarsıttı örneğine yer vermiştir. Bu bağlantılar sar- kökünün "sertleşme, kızma" anlamını burulma saralma ikilemesinde düşünmemizin etimolojik temellerindendir.

Böylece iki kelimeyi yan yana getiren ilişkinin "sarı" rengi ile veya "çevrilmek, kıvrılmak" ile ilişkili olmadığı anlaşılır. ${ }^{15}$

Eklemek gerekir ki sararmak da duygu durumlarıyla ilişkili olarak kullanılır (Şemsettin Sami, 1989: 802) ve sararma'nın da 'çok kızmak' anlamı vardır. Kızarmak gibi sararmak ve sapsarı kesilmek deyiminin bu anlamda kullanılmasının edebiyatımızda örnekleri görülmektedir. ${ }^{16}$ Ancak bizim kelimemiz sarı ile değil sar- fiili ile ilişkilidir.

15 Dîvânu Lugâti't-Türk'te sarılma kelimesi geçmektedir. Ercilasun-Akkoyunlu'nun çalışmasında Er erildi sarıldı "Adam kederden dolayı sarsıldı ve kendisini suçladı" (2014: 97) örneği bulunurken Bozkurt’un çalı̧̧masında ise Beg anar erildi sarıldı "Bey ona kızdı" (2016: 399) örneği bulunmaktadır.

16 Bu konuda Ömer Seyfettin'in eserlerinde örnekler hayli çoktur. Yazar birçok yerde sararma'y1 'çok kızmak' anlamında kullanır. Pembe İncili Kaftan'da ve Diyet'te en can alıcı sahneler "kızardı, sonra sarardı" sözleriyle bağlanmaktadır:

Ayağı öpülmeyen şah, gazabindan sapsarı kesildi. (...) Muhsin Çelebi, kaba Türkçe nutkunu bağırdıkça, Farsça bilmeyen şah kızarıyor, sararıyor, morarıyor, elinde heyecandan açamadığı mektup tir tir titriyordu ... (Bütün Hikâyeleri 3: 21-22)

Koca Ali yine karşllk vermedi. Acı acı gülümsedi. Kızardı. Sonra birden sarardı. Hızla döndü. Bilediği satırların en büyüğünü kaptl. (Bütün Hikâyeleri 6: 22)

Birbirlerini görünce ikisinin tekrar kan beyinlerine çıktı; yüzleri sarardı, dudakları morardı. (Harem: 2) 


\section{ग(৫)}

"Kızmak" anlamındaki sar- kökünden edilgen bir fiil olan sarılmak türemiş olmalıdır. Bu da burulma ile bir ikileme oluşturmuştur. Tahmin edilir ki bu ikilemeyi oluşturan iki fiil, bir anlam benzerliği ilişkisiyle bir araya gelmiş ve anlamlı bir yapı oluşturmuştur. ${ }^{17} \mathrm{Bu}$ anlam ilişkisi ise "kızmak, köpürmek, öfkelenmek" anlamıdır. Bugün her iki fiil kısmen bu anlamını kaybetmiş gibi görünse de bizi bu ikilemeye götürecek iki tanığımız vardır.

\section{i. Eski bir İkileme: Burk Sark Etmek}

Elimizdeki metnin anlamına bizi en çok yaklaştıracak ifadeleri Arat'ın Eski Türk Şiiri eserinde görmekteyiz. Eserde iki ayrı şiirde burk şark ikilemesi geçmektedir (1991: 72, 140) ${ }^{18}$. Arat'ın aktardığına göre burk-şark ikilemesini Yuhadin şu örnekte 'kızmak, gazaplanmak' anlamında almıştır: Burk-şark etip uruşa ketti. “Kızarak çıkışmağa başladı.” (1991: 341-342).

Bu örnek açıç̧a bizim burulma ve saralma'da olduğunu düşündüğümüz anlamı vermektedir. Arat, ayrıca şu bilgileri de nakleder:

burkan şarkan "gürültü patırtı, burk şark tüşüp ıylamak "bağıra çağıra ağlamak", burkanda"gürültülü hale gelmek", k. burkandan-, burkak; burkakta-, burkulda-, "gürlemek, kızgın hâle gelmek". (kirgen buuraday burkuldayt "kızgın deve gibi gürlüyor), burkura- "yüksek sesle ağlamak" Radloff, Wb. burk (Kazak) "kaynarken suyun çıardığı ses” (Su burk kılıp kaynadı) burkura- (Kazak) burkulda- (Kazak), purkura- (Tel.) porkura- (Tel.) (1991:341-342)

Bu bilgilerden sonra Arat, şark kelimesinin ses çıkarmak'la ilgili anlamlarını sıralayıp, metinde geçen burk şark ikilemesini 'ahenksizlik, şöyle böyle' anlamlarında değerlendirilmiştir. Fakat Sertkaya'dan aldığımız bilgiye göre Arat'in burk şark okuyuşunu Zieme burk sark olarak düzeltmiştir (1991: 164) ve bu

17 Benzer bir ikileme örneği olarak Uçar'ın yazısına bakılabilir (2019). Er- ve bar- fiilleri, bur- ve sarfiilleri gibi anlamca örtüşmektedir. Burada yazar er- fiilindeki "var olmak" anlamının bar- fiilindeki varlı̆̆ını sorgulamıştır. Nitekim var- fiilindeki "var olmak” anlamı, Rize ağzında “... (s)ı varan” şeklinde kalıp bir ifadede yaşamaktadır. Örn. Derdi varan (olan) çeker. Evladı varan neyler vs. gibi...

18 Bunlardan ilki: Burk sark kılip on edgüsin men An-tsang özüm / Buyan küsüş öze konmış takşut başlandı (9/78) "Burk sark edip, onun on iyiliği üzerine ben An-tsang / Sevap için bizzat koşmuş olduğum bu parça başlandı." İkincisi: Burk sark kllıp ugulugsuz uluş idigin / Bun orunı birer kogda büdürü idelim (13 C/103-104) "Burk sark ile yapılamayan /tanzim edilemeyen memleket nizamını temelini, her noktada hep birlikte tanzim edelim." İkinci beyitteki burk sark ikilemesi "gürültü patırtı" gibi bir ikilemeye paralel düşünülmüş gibidir. 
ikileme (hendiaduoin) 'kızmak, gazaplanmak' anlamiyla elimizdeki burulma saralma kelimelerini aydınlatmaktadır: bur- sar- $\rightarrow$ bur-u-l-du-m sar-a-l-dl-m.

Bur- kökünün bu şekilde kaf ile ek alması (bur-k), kelimenin kalın sıralı okunacağının da işaretidir. Böylece bu kelimeler çok eski bir deyim olarak teşhis edilmektedir.

\section{ii. Günbed Yazmasında bir deyim: Bura Sara}

Günbed yazmasının dördüncü soylamasında karşımıza çıkan bura sara ifadesi, bur-sar- ikilemesiyle ilişkili olarak düşündürücüdür:

Bura sara çapar olsan düşmana yügürük yeter

At yetürse düşmanı polad keser (G.4a/2)

Buradaki bura sara ibaresi için sayfanın kenarına şu not düşülmüştür: Bura sara sağa sola dimek ma'nasindadır. Araştırmacılar hâşiyede verilen bu anlama sadık kalmıştır: Azmun (2019: 69), Ekici (2019: 160), Asker (2019: 23), Haciyev (2019: 15), Serrafî et al. (2019: 194) ve Rafraf (2020: 20). Sadece Shahgoli et al. bu ibareyi bura sara çapmak şeklinde bir deyim olarak alıp 'sağa sola dönüşler yapmak' anlamını şüpheli olarak vermiş (2019: 236), Quliyev 'kıvrılarak' şeklinde yorumlamış (2019: 40), Rafraf "ardıcıl olmak" anlamını ilave etmiş (2020: 94), Tulu ise cümleyi Sağa sola / bura sara /akın olsa (2020: 266) diye yazmıştır.

Bura sara'nın "çevire döndüre" şeklinde de anlaşılması mümkündür fakat nedense bu şekli deneyen yoktur. Ama ifadenin 'sağa sola' olarak alınması da cümleye bir rastgelelik ve kararsızlık anlamı katmaktadır. Düşmana -en hızlı şekilde- yetişmek için atı neden sağa sola koşturmalıyız? Burada en fazla "çevire döndüre" at ile manevra yapmak kast edilmiş olabilir.

Peki ya haşiyedeki not, unutulmuş bir kelimeye biçilen yeni bir anlamdan ibaret ise?

Rzasoy da bizim gibi bu soruyu sormuş, kitaptaki notun koyduğu blokaj1 aşabilmiştir. Fakat ne yazık ki bu defa da sehven atlanan, unutulan bir harf, yazarı bambaşka bir yere, tın bura, tag bura gibi bağlantılarla bura'nın börü ile eşleştirilip şamanla ilgili görüleceği ve sonunda "at" anlamında işleneceği uzak bir noktaya taşımıştır. Nun harfinin yazıdan düşürülmesiyle bura sara, cümlenin öznesi olmuştur (2020:134; ayrıca bkz. Hacıyev 2019: 14). 
Biz bu ibareyi burk sark deyimi paralelinde ele almayı deneyelim. O zaman bura sara ikilemesini 'kızdırarak, ağzını köpüklendirerek, şiddetli bir şekilde' anlamında düşünme ihtimali belirmektedir. Birbirine bağlı olarak bu üç ikilemeyi çok basit bir açıklamayla şu şekilde sıralayabiliriz:

\begin{tabular}{|c|c|c|c|}
\hline burulma saralma & kızma, köpürme & $\begin{array}{l}\text { geçişsiz fiil (öznenin kendisi } \\
\text { kızıyor) }\end{array}$ & buruldum-ise saraldım-ise... \\
\hline burk sark etme & kızma, köpürme & $\begin{array}{l}\text { geçişsiz fiil (öznenin kendisi } \\
\text { kızıyor) }\end{array}$ & burk sark edip uruşa ketti. \\
\hline bura sara & kızdıra köpürte & $\begin{array}{c}\text { geçişli fiil (özne "at"ı } \\
\text { kızdırıyor) }\end{array}$ & bura sara çapar olsan... \\
\hline
\end{tabular}

Metinde bura sara at koşturmak düşmana yetişmenin, düşmana yetişmek de düşmanı polatla kesme'nin şartı olarak sunulmuş olmalıdır: “(Atı) bura sara koşturursan hızlı at düşmana yetişir. At yetiştirirse düşmanı kılıç keser."19

Koşmak anlamına gelen çapmak, daha çok "at koşturmak" anlamıyla karşımıza çıkmaktadır. Yügürük de (yüvrük, yüğrük) hızlı koşan, çevik atlar için kullanılan bir tanımlamadır (Tekin et al., 1998: 713). Kumuk Türkçesinde yügürük at için kullanılan şu atasözü, soylamadaki ifadeyle oldukça benzer bir sahne sunar: Atın yügürük busa barandan korkma. "Atın yüğürük olsa düşmandan korkma.” (Güllüdağ, 2002: 165). Bu yüzden ilk cümleden atı dışlayamayız.

Bir düşman kovalama sahnesinde 'atı şiddetli bir şekilde, adeta bağırtarak, coşturarak koşturmak', 'sağa sola koşturmak'tan veya 'atı sağa sola koşturmak'tan daha anlaşılır bir harekettir. ${ }^{20}$

19 Azmun'un çevirisinde yögürük kelimesi at ile ilişkili olarak düşünülmemiştir: "Sağa sola koşturman gerekiyorsa düşmanı ancak hızlı olan yakalar." (2019: 69). Ekici'nin "Sağa sola at koştursan düşmana yügürük yeter. At yaklaştırsa da düşmanı çelikten kılıç keser" şeklindeki çevirisinde "de" bağlacı, metnin anlamını farklı bir istikamete çevirmektedir. Kanaatimizce metnin anlamı şu şekilde belirginleşebilir (çeviri değildir): Koşturmasını bilirsen düşmana at yetiştirir (bu kolaydır). Düş̧ana yetişince de artık düssman kesmek kılıca zor değildir. İlk cümlede ata binecek yiğidin hüneri, ikinci cümlede atın düşmana yetiştirmesinin önemi vurgulanmıştır. Soylamanın devamında da katı yaylar için "bilek", ötkün oklar için de "parmak" marifeti övülmektedir. At binenin kılıç kuşananın sözü bu parçaya uygundur.

20 Atı bu şekilde koşturmanın, günümüzde motosikleti "bağırtarak" sürme olgusunun arkaik şekli olduğu akla gelebilir. Ümid ederim bir ilgisi yoktur. 


\section{ग(৫)}

Aşağıdaki anlatımlar, atın savaş meydanında nasıl koştuğu veya koşturulduğu (çapıldı̆̆ı) hakkında fikir verir. Nitekim savaş filmlerinde at koşturma sahnelerinin atlanmayan bir ayrıntısı olarak bu durum gözlemlenebilir. Örneklerde acı köpük ve taban kızması ile atın koşması birlikte anılmaktadır:

Arpa verüb sahlayanda bedev atlar er kanatı, güni gelse, demi düşse arhu dağdan arḩu dağa sıçratmasa, acı köpük kan terlere baturmasa, arpa verüb saḩlayanda bedev atlar neye yarar, neye yarar? (G.7b/11)

... yanaşanda kıçkıranda, önce gelür, öncil alur, er elinden cılav dartar, köpük saçar, daban kızar, göz çerelür, dağ gözedür, iyesini sağınduğu yerlerine yetürür, ol meydandan çıhar, koymaz (G.11b/10).

... savaş güni at güclüsi, yanaşanda, kıçkıranda, ön olanda, önce gelür, öncil alur, er elinden cılav dartar, el ganime yetürür, yügürük aşlı bedev soyı. (G.15b/2).

Savaşma ile ilgili bir hareketin abartılı bir şiddetle yapılmasına dair övgüler, Dede Korkut metinlerinin üslubuna yabancı değildir. Katı yay çekilince kabzanin ayrılması (G.9b/6), eğini bek demür donun sökülmesi (D. 66b/9) gibi örnekler, savaşa atılmadaki gözükaralığı örneklendirir. Er malına kıymayınca adı çıkmaz (D.3b/11), Dede Korkut'un başlıca öğütleri arasındadır.

Bura sara'yı da bur- sar- etimolojik örüntüsü içinde ve köpürmek ile ilişkili olarak değerlendirmek metnin ifade kapsamına yakışacaktır. En azından bu ifade üzerine bir soru işareti koymak gerekir.

Sonuç olarak 17. soylama başlangıcında geçen burulup saralma ifadesinin bir kızma, gazap duygusuna karşıllk gelmesi konusunda elimizde burk sark ve bura sara ikilemeleri vardır. 'Bulut olmak' da burulup saralma'nın 'gazap etme' anlamina uygun bir "teşbih" unsurudur. Bulut olmak, çalışmamıza göre bir dönüşüm hikâyesi değildir, bir 'hiddet' betimlemesidir. Günümüz algılayışında bulutun yağmurdan dolayı hüznü çağrıştırması, eski Türk düşüncesinde buluta atfedilen 'yiğitlik' anlamına ve 'esip gürleme' fiiline aykırıdır. Buna ilave olarak burada bulutun bir rahmet ve bereket kaynağı olarak anılmadığını da söylemeliyiz. Kazan'ın bulut teşbihi, bulutun korku salan gücüne bir atıftır. Gü̧̈ ise, korku salmadaki etkisiyle ölçülmektedir. 


\section{Bulutun Sembolik Anlamı: Kızdığında Bulut Olmak}

Kazan'ın burulup saralmasl, kızması, gazap etmesidir. Böylece Kazan kendi kahramanlıklarını anlatacağı bu soylamayı bir meydan okumayla açmakta, bulut gibi kararıp gürlediğini, düşmana korku salıp onları bunalttığını söylemektedir. Bulutun insanlara bir tehdit olan gücünü kendi vasfi olarak sayan Salur Kazan, "gazap ettiğinde" (veya acı̆̆ı tutanda) neler olacağını bu şekilde duyurur. Böylesi bir meydan okuma, bizi görkemli bir kahramanlık anlatısına hazırlayacak ortamı sunar. Bu metni yorumlarken, ise bağlacının sağladığı eksiklenmeme, büyüklenme ve umursamama edası da önemli bir ayrıntı olarak Kazan'ın hükmedici üslubunu tamamlamaktadır. Bu söyleyiş hususiyetinden dolayı, metni günümüz Türkçesine aktarırken anlamın aynı şekilde muhafaza edilmesinin zorlaştığını da söylemek mümkündür.

Dikkate değer bir ayrıntı da Kazan'ın "gökyüzünde" bulut olmasını takip eden ifadelerindeki "yönelme" ifadesidir. Yönelme ifadesi, anlatıma "yerini bulma" havası katmaktadır. Bulut olan Kazan, alçak yerler-de değil alçak yerler$e$ çiskin olmaktan, dağ başın- $a$ duman olmaktan söz eder. Bu ifade "başa belâ olmayı, düşmana duman gibi çökmeyi” andıran bir ifade tarzı olarak cümlenin tehdit havasını kuvvetlendirir. Özellikle "yüce dağlar başına duman olmak" başlı başına bir iktidar, bir büyüklenme ifadesidir.

Kazan'ın bulut olmasının neden bir gazap duygusuna karşıllk geldiğini söylemek için sırasıyla üç konuyu daha açmaya ihtiyaç vardır: Birincisi, korku, güç ve öfke arasındaki ilişki, ikincisi bulutun bir öfke sembolü olması, üçüncüsü ise Kazan'ın bulut ile vasfedilmesinin örnekleridir. İlk ikisi bulut metaforunun genel çerçevesini tanımlamak işlevindedir. Üçüncü konu ise bulut olmayı niçin bu şekilde anlamlandırmış olduğumuzun en temel dayanağını tanıtmaktadır.

\section{Korku Salmak ile Güç Arasındaki Îlişki: Öfkenin Övgüsü}

Üstün güçler, eski çağların bilincinde insanlara boyun eğdiren, itaat ettiren güçler olarak tanınmaktadır. İtaati sağlayan en temel duygu ise korkudur, dehşet duygusudur. Üstün güç, etrafa dehşet saçan, kontrol edilemeyen, ölçüsüz şekilde şiddet gösterme gücüne sahip varlıklardır. İnsanların durdurulamayan ve "ehil olmayan” bir güç karşısında hissettiği korku, bu korku kaynağına karşı bir hayranlığı da beslemiştir. Aslan, kaplan, kurt gibi yırtıcılar gibi bulut da, aynı 
korku ilişkisiyle bir üstün güç sembolü olmuştur. Büyük destan kahramanları, insanlara boyun eğdirme, düşmanı dize getirme konusunda bu heybet sahibi, ihtişamlı yaratıklara teşbih olunmaktadır.

İktidar için korku, insanın yönetilmesi için birinci vasıtadır. ${ }^{21}$ Bu yüzden iktidar, aynı zamanda bir korku sembolü olma çabası içindedir. Bu konuda Cengiz Han'ı tarihteki önemli bir örnek olarak sayabiliriz. Birçok tarihçi Cengiz Han'ın başarısını, uyandırdığı dehşet duygusuyla, yayılan katliam haberlerinin yol açtığı psikolojik etkiyle yorumlamaktadır. Bu korkuyu bir kez uyandırdıktan sonra zafer kaçınılmaz olmuştur. (Bu konuda bk. Durak, 2014). Destan metinlerinde de kahramanlar, merhametli yönlerinden daha çok dehşet salan yönleriyle anılmaktadır. Özellikle Günbed yazması, kahramanların dehşetle ilişkilendirilmesinde çok can alıcı sahneler sunmaktadır. Kahramanların vasıflarının sayıldığ 19 . soylamaya bu konuda müracaat edilebilir. Bir kalenin ne şekilde fethedebileceğine dair bir bakıma taktikler veren bu soylamada Kadir Tanrı gölgesi olarak anılan Bayındır Han şu şekilde de övülmüştür:

Yeri getür deyende ötkün ${ }^{22}$ sözli

Hay demedin baş götürür yüz cellâdlı (G.12a/9)

Salur Kazan için de

... kavatlara kan utdurub ceza veren

kaynar deniz kursakll, kara pulâd yalmanı

sür cidanın cibiri, katı yaylar kabzası

(...) al kayada ala kaplan enigünin diskirgeni

Gür mişenün kollarında ${ }^{23}$ kakan aslan eniginüy högürgeni

kayış dilli kurt eniginün kapkuncısı (G.12b/1)

${ }^{21}$ Devletin kültürümüzde "baba" olarak görülmesi, yönetime (iktidar olmaya) yapılan bir vurgudur. Toprak ise besleyici, koruyucu, şefkatli rolüyle bir anadır. Bu değerlendiriş toplumsal cinsiyet kalıplarıyla anlamlı olmaktadır.

22 Ötkün oklar çıkardığı ses ile düşmana dehşet salan ıslıklı oklardır (bk. G.4a/4; burulmayub doğrı çıkan). Buna göre ötkün söz'le Bayındır'ın "gürlemesi"nin dehşet salıcılığı vurgulanmış olur. Günümüzde ıslıklı ok geleneği yaşatılmakta ve İstanbul'da okçuluk festivallerinde yüzlerce okçunun aynı anda ok attığ 1 "ses getiren" gösteriler düzenlenmektedir

${ }^{23}$ Kefle yazılan bu kelimenin okunuşu ihtilaflıdır. Ekici göllerinde diye okumuştur (2019: 75). 
şeklinde övgüler sıralanmış, kahramanın savaşçılığı ve saldırganlığı kaplanla aslanla özdeşleştirilmiştir. ${ }^{24}$ Aynı metnin devamında Kıyan [Selçük] oğlu Deli Dündar da ürkü salmak, tepüp almak, er böğürtmek gibi dehşet ifadeleriyle anılmıştır:

\author{
Minkışlak'uy içine ürkü salan \\ Lezgi-yilen Dâgıstân'a tûfan salan \\ Demürkapı Derbend'i tepüb alan \\ tepdüginde ganîminden kayıtmayan \\ yarma kabak cidasınuy ucında er böğürden (G.13a/1)
}

Yiğitlerin takdim sözlerinde bunun gibi örnekler çoktur. Kiyan ve Boğaç, adlarıyla doğrudan dehşetle ilişkilendirilen Dede Korkut kahramanlarıdır. ${ }^{25}$ Bütün bu övgülerle vurgulanan, kahramanların güçlü ve dolayısıyla korku salan olmasıdır. Geçmişten günümüze birçok devlet için kartal, ejderha gibi vahşi hayvanların millî sembol olarak kullanılması, korku salmayı ifade eden sözlerle marşlar oluşturulması, korku-iktidar ilişkisine dair en bilinen örneklerdendir.

Birçok destan kahramanının savaşçılığın bir övgüsü olarak Deli adını alması da ki bu soylamada Kazan'ın eski adının Deli Dönmez olduğunu öğrenmekteyiz, bu güç tasavvuruyla ilişkilidir. Deli olarak anılan kahraman, taşkın hareketleriyle etrafa dehşet saçar, bilinen kuralları alt üst eder (Haznedaroğlu, 2020a: 174-175). Kahramanın ehil olmaması, vahşi olması, yeme içme ve uyuma davranışlarındaki ölçüsüzlük ile de ortaya konulmaktadır. Yedi gün boyunca uyuma (D.137b/12), on koyun ile doyamama (toksan koyun dovgallk on koyun öyünlük yetmeyen T.O. 1/37), bir güçlülük vurgusu olarak zikredilir. Beşerî ihtiyaçlardaki bu ölçüsüzlük, kural tanımazlık ve dizginlenemezlik, kahramanların boyun eğdiren vasfına

${ }^{24}$ Bu özdeşleştirmede eniği ifadesi 'mensup olmak' ile ilgili bir anlam taşısa gerektir. Aslan eniği yine aslandur. (D.23a/4) Kahraman bazen aslan, bazense aslan yavrusu olarak anılır. Ejderha ile savaştığı boyda Kazan'1 Lala Kılbaş bu ifadelere benzer şekilde övmüştür (G.28a/8).

25 Tulum'un önermelerine göre birçok Dede Korkut kahramanının adı "kan dökmekle ilgili" bir buyruktan gelmektedir: Bük, düz > Bügdüz, Er yüz > Erüz, Sal, vur > Salur vs. gibi (2015). Ancak özellikle Sal-vur şeklindeki etimoloji sağlıklı görülmemektedir. Oğuz'un 24 boyundan biri olan Salur adı, Azmun'un verdiği bilgiye göre "hareketli, saldırgan" anlamındaki Salgur'dan gelmektedir. Kırzıoğlu, Topkapı Oğuznamesi’ndeki SALWR yazılışlı kelimeyi Salvur şeklinde okumaktadır (2020). Bu Oğuzname metninde kelime bazen de SALYR şeklinde yazılmaktadır (34. satır). 


\section{J(৫)}

önemli katkılar yapan hususlardır. Ölçüsüzlük, bilinmezlik, dünya üzerinde bir denge arayan insan bilinci için ürkütücüdür.

Boyun eğdirmek, korku salma gücüne bağlandığı için, bir yiğidin övgüsüyle ilgili benzetmelerde öne çıkan duygu da öfke ve heybettir. Halk dilinde de "dellenmek" öfkelenmek anlamındadır. Öfkenin ve kahramanın öfkelendiğinde ortaya çıkacak gücünün, destan kahramanlarının önemli bir vasfı olarak övgü konusu edildiği görülmektedir.

Öfkenin methedilişini, kahramanın arzu(lama) gücünün bir uzantısı olarak değerlendirmek mümkündür. İstediğinde "çok isteyen”, önünde engel tanımayan kahraman, istemediğinde de çok yıkıcıdır, ezip geçme kudretine sahiptir (Kanturalı örneği). Kahraman kahretme kuvvetiyle kahramandır. Böylece bütün intikamını almakta, bütün saldırılara karşılık verebilmektedir. Öfkenin övgüsüne dair

Acıgı dutanda kara daşı kül eyleyen... Kara Göne (D.31b/10) ile;

Acıgı dutanda bıyıklarından kan çıkan, bıyıgı kanlu Bügdüz Aman (D.33a/5)

örnekleri verilebilir. Bügdüz Aman'ın bıyı̆̆ının kanlanması Günbed yazmasında daha ayrıntılı verilmiştir: Hayhıranda bıyıglarınuy dibinden bugdâ daneli kan daşlanan. (G.14a/6).

Acığ l tutanda ifadesi 'hiddeti tutunca, öfkesi kabardığında' diye çevrilmektedir (Ergin, 1971: 117; Tulum \& Tulum, 2016: 19) Dede Korkut Kitabı'nda acığı tutmakla ilgili sahneler çoktur (Bk. D.31a/13, D.39a/9.). Yeni bulunan yazmada da birkaç yerde aslan için acıklı aslan ifadesi geçer ve buradaki acıklı da 'öfkeli, kızgın' anlamında anlaşlır (Azmun, 2019: 74; Shahgoli et al. 2019: 228). ${ }^{26}$ Altay destanlarında da kahramanlar için 'öfkelenmek' anlamında açırganmak tabiri geçmektedir. Aslanın kızması, yelelerini kabartıp kükremesi şeklinde bir tabloyu resmeder. Büyük kahramanların heybeti de bu yüzden aslanla birlikte anılagelmektedir. Burada öfke, başka her çeşit duygunun ve aklın da önüne geçen kuvvetli bir duygudur. Öfkenin akla, mantığa, bedenin sinırlarına (ve kalbin isteklerine de) galebe çalması, kahramanların en çok takdir edilen vasıflarındadır. Öfke duygusunun aslanla birlikte anılmasına şu şiir iyi bir örnektir:

26 Ekici, bu kelimeyi ‘aç aslan' olarak çevirmiştir (2019: 172). 


\section{$\mathrm{J}(\mathrm{O})$}

Öpkem kelip uğradım / Arslanlayu kökredim

Alplar başın togradım / Emdi meni kim tutar (Ercilasun \& Akkoyunlu, 2014: 62)

Öfke gücü, kahramanın savaşabilme kabiliyetidir, düşmanı kahretme kudretidir. Bu yüzden övülür ve bir erdem olarak sunulur. Şan Kızı Destanı'nda Hiddetlendiğinde sadece tek bir bakışla öldürebilen kudretli Alp Barıs saf dilli bir devdi. denilmektedir (Nurutdinov, 1991: 48). Öfkeli olmanın iyi olmaya zıt bir değer olmaması bugün olumsuz anlamda kullanılan bazı kelimelerin de geçmişte övgü sözü olarak kullanılışını açıklar (boğa, deve, zorba vs.).

Koblandı Batır Destanı'nda Kobland1, rakibi Kazan'1 tehdit ederken metnimizde Kazan'in bulut olmasını anımsatacak bir ifade kullanmaktadır:

Betimnen kahar şı̆̆adı

Jaybırlı karday aralas

"Yüzümde kahır ifadesi var. Yağmurla karışmış kar gibi." (Kuanışbayeva, 2002: 175).

Destan kahramanlarının sakin olması, öfke göstermemesi, destanın hedeflediği temel duygulara ve çatışma kurgusuna aykırı olacaktır. Yukarda örneklediğimiz takdim sözlerinden, büyük kahramanların öfkelendiklerinde veya kızdırıldıklarında mutlaka çok sert ve görkemli bir karşlıkta bulunmaları gerektiği şeklinde bir hüküm de çıkarılabilir. Bir hamlenin yapılmasını gerektiren bir durumda gereken hamleyi yapmamak, her ne sebeple olursa olsun olaylara en güçlü karşıllğı vermemek, gücünü ortaya koyamamak demektir. Gücünü ortaya koyamamış olmak ise başına kakınç, yüzüne tokunç edilecek bir meseledir. ${ }^{27}$ Destan kahramanları böyle bir durumu kabul edilemez bulurlar.

Dede Korkut metinlerinde öfkenin yutulmasının veya ortaya çıan bir intikam durumuna karşı hemen mukabelede bulunmamanın erkekler için erdem olarak sunulduğu bir tablo görmek zordur. ${ }^{28}$ (Bay Büre oğlu Bamsı Beyrek hikâyesi bu konuda bir istisna olarak ayrılabilir.) Temel amaç düşmanı sindirmektir ve sükûnet buna uygun bir zemin olarak görülmeyecektir. Kahramanlı̆̆ı örnekleri

27 Bu fikri özetleyici bir tablo Kanturalı hikâyesindedir: Baba! Bu sözi bana dimemek gerek idün. Çünki didün, elbette varsam gerek. Başuma kakınç, yüzüme tokunç olmasun. (D. 89b/4)

28 Dede Korkut hikâyelerinin kadın kahramanları bu hususta farklıdır. İntikam ve karşllık verme misyonları geri plandadır. Akılıı davranır, tedbir alır, üzülür, ağlar, kızdıklarında ise kargış ederler. Onlardan beklenen, sakinleştirmeleri veya geride durmalarıdır. Deli bahadır olmamalıdırlar. Selcen Hatun bile şöyle der: Uyarmak benden, savaşuban hüner göstermek senden (D.98b/2). Öğinür-ise er öğinsün, aslandur (D.101a/3). 
de bu yüzden sükûneti temsil eden, narin varlıklar değil, aslan, kaplan, şahin gibi vahşi, yırtıcı hayvanlar ve yıldırım, şimşek gibi güçlü tabiat olaylarıdır. Bu sebeple Kazan'ın "burulduğunda saraldığında" buluta dönüşmesi bir tehdit ve meydan okuma olarak anlaşılmalıdır.

\section{Bir Korku Kaynağı ve Erkeklik Sembolü Olarak Bulut}

Türk düşüncesinde bulutlar gök gürültüsünün, şimşeklerin ve yıldırımların kaynağı olarak tanınmıştır ve esip gürlemeden dolayı kızgınlıkla, yüce bir gücün gazabıyla özdeşleştirilmiştir (Ögel, 2014). Gök ile yer arasında "kılınan" insan, gökyüzünden gelen bu açı saldırılar karşısında çaresizdir. Dolu, şimşek, yıldırım ve firtına, bulutun saldırı silahları olarak görülmüş ve saldırılara duyulan korku, gök kültünün en önemli kaynaklarından olmuştur.

Bulutun bir "rahmet, bereket" simgesi olduğu anlamı da mitolojik kültürde ve inançlarda derin bir yer etmiştir. Bu konuyla ilgili Türk dünyasında Burgut veya Bürgüt Ata inancı da vardır. Türkmenlerde, Burkut Ata bulutlara hükmeden ve yağmur yağdıran, bolluk ve bereket timsâli kutsal bir varlıktır (Gökçimen, 2010: 69). İslâmiyet'ten önce insanların kendisine adak sunduğu Burgut Ata, İslam sonrası bir veli veya peygamber karakteri kazanmıştır. Yağmur yağdırmak veya yağmuru yönlendirmek, Orta Asya halklarında Garrı Mama, Mama Kuldurak gibi kadın hâmi ruhlar tarafından yerine getirilmektedir (Bayat, 2007).

Bulut, Türkmen halk edebiyatında bereketi, kutsallığı temsil eden bir "ana" olarak yer almaktadır. Ona Garaca Mâma da denilmektedir. Bulutun gümbürdemesi ise Garaca Mâma'nın gocuğunu (içme) atması olarak yorumlanmaktır. Kazan'ın bulut olmasını kutsallıkla ilişkilendiren Azmun'un yorumlayışında, bulut gibi dağların da kutsallıkla bağlantılı olarak düşünüldüğünü ekleyebiliriz. Dağlar eski Türk düşüncesinde kutsal kabul edilir. Dağlara verilen Dağ Baba, Dağ Ata, Tanrı Dağı gibi isimler, dağların kutsallığıyla ilişkilidir. Mitolojik bir kavram olarak yir 'yer' Şamanizm'de kutsal sayılan dağ ile ifade edilmektedir. Hatta dağ gibi dağda yaşayan hayvanlar da kutsaldır. (Azmun, 2018: 36, 53).

Bulutun kutsallık anlamının kadim inanışlarda önemli bir yer tuttuğu görülmektedir. Zeynep Canan Koçak, bulut metaforunun arkaik temellerini konu aldığı makalesinde, bulutun eski dünyada ilâhî bir tezahür olarak görüldüğünü, 


\section{J(৫)}

İslâmî gelenekte de ilâhî bir görevli olarak anlamlandırıldığını söylemektedir (2018). Bu ilâhi görevli, bazen Allah'ın rahmetini, bazense gazabını taşımaya aracıdır. İsrailoğulları'nın inanışlarında bulut, Tanrı'nın onların yanında olduğunu gösteren, yol gösterici bir metafor olarak sıkça anılmaktadır.

Türk destanlarında buluta verilen anlamları değerlendirirken öncelikle bulut imgesinin "güç" ve "şiddet" ile ilişkilendirildiğini göz önünde bulundurmak gerekir. Böylece soylama girişlerinde bulut imgesinin neden yiğit için örnek olarak sunulduğunu da anlamış oluruz:

Kara bulut erdemidür gökde örilmak. ${ }^{29}$

Kay busaluk erdemidür tökelin töküb yere sinüb yer su doymak (G.16a/4)

Kara bulutun erdeminin göğü kaplamak (veya gökte yükselmek) olması, bir yiğit için bulutu bir örnek olarak imler. Burada yerin suya doyması, bulutun yağdırmasıdır. 6. soylamada bulutun gücüne vurgu çok daha öne çıar. Bulutun gürlemesi yetmemekte, “yağması" istenmektedir. Bu yüzden örnek kahramanımız Kazan da bulut olmakla kalmamış olmalıdır:

Yel çeküben götürende gelende yelgin bulut, yel yetürüb yagmasa yagdurmasa, ol bulutuy gürüldeyüb şakıldayub esibeni geldigü neye yarar neye yarar. (G.6a/3)

Diğer yandan bulutun kontrol edilemezliği, aşkın oluşu, yıldırımların ve gök gürültüsünün kaynağı olması, bulutu güçlülüğün ve şiddetin bir remzi kılar. Dilimizdeki bulut gibi kararmak, bulut gibi kabarmak, duman gibi çökmek, suratı bulut olmak şeklindeki deyimler de bulutun "güçlü bir varlık" oluşundaki öfke ve şiddet temasina vurgu yapan deyimlerimizdendir.

29 Örilmak elif ve kaf la yazılmıştır (AWRLMAQ) ve metinde bu şekilde kaf'la yazılan eksilmak, eglenmak, tükenmak gibi kelimeler vardır. Azmun, bu kelimeyi urulmak şeklinde okuyup 'gümbürdemek' olarak anlamlandırmıştır (2019: 78). Quliyev de urulmak (2019: 56); Shahgoli et al. (2019: 213), Serrafî et al. (2019: 281) ise urlamak olarak okumuştur. Haciyev, bu kelimeyle ilgili Azmun ve Ekici'nin okuyuşlarını eleştirerek "วslində, cümlənin mənası daha sadədir: Qara bulud hünəridir göydə (toqquşub) gurlamaq" (2019: 40) demektedir. Biz burada ince sıralı okuyuşu, Topkapı Oğuznâmesi'ndeki kara bulut örgüni ifadesiyle uyumlu bulduğumuz için tercih ettik. Ancak "gürlemek" ilişkisi de herhalde bu cümleye uygundur. Nitekim Tezcan ürgün kelimesini ‘bulut kasırgası' olarak değerlendirmiştir (2020: 231).

30 Bu okuyuş da ihtilaflıdır. YYRASYNWB yazılışlı kısmı Azmun yer esinüb (2019: 47) şeklinde, Rafraf, YYR SWDWYMAK yazılışlı kısmı yer soyutmak şeklinde okumaktadır (2020: 40). 
Yunus Emre'nin “salkım salkım olan bulut”u da bu bağlamda hatırlanabilir. Dağları "harami gibi yol kesen" ve "taş bağırlı" olarak anan Yunus, bulutu da "şiddet" temasıyla birlikte düşünmüş, serzenişe konu etmiştir:

Saçın çözüp benim için

Yaşın yaşın ağlar mısın

Bulutun "saçını başını dağıtarak şimşekler saçarak" yağmur yağdırması, (gazap etmesi), alpların vuruşma sahnelerini andırmakta ve Kazan'la ilgili yapılan teşbihi bir kere daha aydınlatmaktadır.

Birçok mitolojik anlatıda "yıldırım" silahını kullanan göksel varlıklardan söz edilmiştir. Şan Kızı Destanı'nda bulutlar başlı başına bir varlıktır ve intikam alma kabiliyetine sahiptir. Bulutlarda ateş yakıp onları karartan ve kızdığında "yıldırım vuruşu" yapan Kubar, bulutları mesken eden ve "kötü olmayan" bir devdir. Rüzgârlara hükmeden Cil ile yıldırıma sahip olan Kubar tartıştıklarında, insanlar için büyük sıkıntılar doğuran fırtınalar kopmaktadır (Nurutdinov, 1991: 50, 56). Görülüyor ki insanların anlam verme çabası içinde bulut önemli bir yerdedir.

Uygur edebiyatında ise bulut, kök luu'nun (gök evreninin) bir şeklidir ve gök gürültüsü de bu evrenin/ejderhanın kükremesi olarak görülmüştür (Esin, 1969: 163). Bulutun ejderha olması, ele aldığımız soylamada "bulut-çiskin-duman" teşbihinin hemen ardından ejderha teşbihi geldiği için ayrıca önemlidir. Günbed yazmasında ejderhayı yendiğinin hikâyesi de anlatılmış olan Kazan için, bulut gibi ejderha da kahraman betimleyen üstün bir güçtür.

Şiddetle ilişkili olarak "bulut” kelimesine eril bir anlam verildiği burada göz ardı edilmemelidir. Eski Türklerde yağmuru ve rüzgârı gönderdiği için, gök eril kabul edilmiştir, yüksek tepelerde de -Tanrı'ya yakın olduğu için- babalık vasıfları vardır. Bu sebeple gökle ilgili olan bulut, yıldırım, şimşek gibi isimler de, hep erkek adları olagelmiştir (Doğan, 2011: 95-96). Buluta verilen eril anlamla uyumlu olarak, gök gürlemeleri bulutların naraları ve kükremeleri olarak düşünülmüştür (Ögel, 2014: 351) . Bulutun bir yiğit olarak vasf edilişini, aşağıdaki parçalarda görmek mümkündür:

Ağdı bulıt kükreyü “Bulut kükreyerek yükseldi.” (Ercilasun \& Akkoyunlu, 2014: 152)

Bulutlar kamu kökreşdi “Bulutlar hep birden gürledi.” (Ercilasun \& Akkoyunlu, 2014: 297) 
Yorıglı bulıt-teg yigitlikni ıdtım "Gençliğimi-yiğitliğimi yürüyen bulut gibi geçirdim."

(Kutadgu Bilig, 6521)

Bulutun sebep olduğu dehşet duygusu için yine Dîvânu Lugâti't-Türk'ten şu örnek verilebilir:

Ördi bulıt ınraşu / Akdı akın muyraşu

Kaldı bodın tạlaşu / Kökrer takı mạraşur

"Bulut gürleyerek belirdi. Ondan şarıl şarıl seller aktı. İnsanlar şaşkınlık içinde kaldılar.

Şimşek çakıyor, gök gürlüyor, yıldırım beliriyor.” (Ercilasun \& Akkoyunlu, 2014: 512-513).

Bulutun kararması, dolu ve yağmur göndermesi, dumanla etrafı sarması, insanlara bir azaptır; onları şaşırtan, onlara yollarını kaybettiren, bazen onları öldürebilen bir güçtür. Altay destanlarında kara dağın iyesinin istemediği kişiye karş1 kara tumanın bojodıp (bırakıp) yolunu kötüleștirmeyi düşündüğü ifadesi geçmektedir (Dilek, 2002: 69). Dumanla özdeşleşen bir fiil olarak çökmek kelimesi, karanlı̆̆ın çökmesi, dumanın basması gibi olumsuz bir durumu ifade etmektedir (Güncel Türkçe Sözlük). Kahraman da düşmanın üstüne bir duman gibi çöker.

Kahramanın savaşçllı̆̆ının yağmur, dolu gibi tabiat olaylarına benzetildiğinin örnekleri de görülmektedir. Kazan Bey oğlu Uruz'un düşmanla bir vuruşması şu şekilde tarif edilmiştir: Sanasın kim daz yerlere dolı düşdi. (68b/6) (daz 'otsuz')

Bunun gibi Dede Korkut Kitabi'nın deyimleri arasında yel gibi yetip yellim gibi yapışmak da yiğidin düşmana hamle etmesini betimleyen bir ifadedir: Kazıllk Koca anı gördiginde yel gibi yitti yelim gibi yapışdı. (D.103b/5 ve 107a/11)

Bulut metaforuyla ilgili dikkat çekici bir hikâye, evinin yağmalandığı boyda Kazan'ın gördüğü rüyanın anlatımında geçmektedir. Kara kaykulu bu rüyada bulutlar ve dumanlar vardır ve kötü bir tablonun unsurlarıdır:

Gökden yıldırım ağ ban evüm üzerine şakır gördüm

Dum kara busarık ordumun üzerine tökilür gördüm

Kuduz kurtlar evüm dalar gördüm (D.23b/1)

Bulutlar ve dumanlarla kasvetli bir tablo sunan bu rüya, hikâyeye göre hayra yorulmamıștır. Nitekim bugün dahi rüya tabiri sitelerinde bu kelimeler aratıldığında olumsuz yorumlar çıkmaktadır. Kara Göne'nin bu rüyayı yorumlarken söylediği sözler ise kara bulut örgünü olarak anılmış olan Salur 


\section{ग(৫)}

Kazan için ayrıca not alınmalıdır: Kara bulut didüğün senüy devletügdür. Kar ile yağmur didüğün senün leşkeründür. Saç kaygıdır, kan kadadur. (D.23b/7).

Dumanın düşman saldırısıyla birlikte anılışı hakkında Begil oğlu Emren boyunda çok önemli bir temas vardır:

Kara kara daglardan habar aşmış

Kaylu kaylu sulardan habar giçmiş

Demür-kapı Dervendi'nden habar giçmiş

Alaca atlı Şökli Melik katı pusmış

Pusdigundan kara taglara duman düşmiş

Yatdıgu yirde Beg Begil'i dutuy dimiş (124a/5)

Buradaki pusmuş kelimesi ardından gelen pusdugindan ifadesiyle birlikte farklı yorumlanmaktadır. Ergin, buradaki ifadeyi "Şökli Melik müthiş pusu kurmuş. Pususundan kara dağlara duman düşmüş” diye çevirmiştir (1971: 192). Pus- okunacak şekilde yazılmış olan kelimeyi Tezcan 'kızmak' anlamından dolayı puş- olarak düzeltmekte (2018: 333) ve Özçelik de puşduğından şeklinde kullanılmış olan kelimedeki zarf-fiile dikkat çekerek bu okuyuşa destek vermektedir (2009: 163). Buna göre yukardaki ifade, Tulum'un da kitabına aldığı şekliyle "Şökli Melik çok kızmış. Kızdığından kara dağları duman bürümüş" olarak çevrilmiş olmaktadır (2015: 294). ${ }^{31}$ Tezcan'ın buş- fiiline sunduğu örnek de bu konuda aydınlatıcıdır: Taga daşa buşusından duman çöken (T.O. 1/34)

Metindeki pus kelimesini okumada bir ikilik olsa da olumsuz bir durumun dumanla ilişkilendirildiği açıktır. İlk yorumu esas alırsak bu, bus, busar- ve busu şeklindeki etimolojik örüntüyle sanatlı bir söyleyiş ortaya çıkmış olur. Çünkü pusmak hem 'tuzak kurmak' anlamına hem de 'sinmek, saklanmak, gözetmek, gizlice takip etmek' anlamlarına gelmektedir (Axundov 2006/3: 628b). Ayrıca kelimenin 'pusarık, bulutlu, dumanlı' anlamları da bulunmaktadır (Güncel Türkçe Sözlük). Diğer yorumda ise öfkeyle duman arasında bir ilişki kurulmuş olur. Her iki yorum da bulutun öfke yahut şiddetle ilgili olduğu düşüncesini desteklemektedir.

31 Hikâyenin devamında yine şöyle bir cümle geçmektedir: Şökli Melik sana katı pusdı. (125b/13). Burada da aynı okuyuş ve anlama ikiliği vardır. Her iki ifade de anlamca uygun görünmektedir. Salur Kazan tutsak olup oğlu Uruz’un çıkardığı boydaki ejderhalı övünmede Heybetinden sol gözüm pusardı (D.141a/7) denilmektedir. 


\section{J(৫)}

\section{Kazan'ın Bulut Olarak Vasfedilişi}

Dede Korkut Kitabinın en çok methedileni olan Salur Kazan hakkındaki övgülerde "bulut" ifadesi geçmektedir. Kara kaykulu düşü yorumlarken Kara Göne kara bulut için Kazan'in devleti (D.23b/7) yorumunu yapmıştı. Kara Göne'nin bu yorumu düşman saldırısı hakkında bir değerlendiriş olabilir ancak kara bulut örgünü sözünü Salur Kazan için kullanılmış olan önemli bir övgü sözü olarak görmekteyiz. Bu sebeple Kazan'ın “bulut olduğunu” söylediği elimizdeki soylama başlangıcıyla bağlantı kurulacak ilk metin Topkapı Oğuznâmesi'ndeki Kazan övgüsü ile ilgili ben Kazan redifli soylamadır. ${ }^{32}$ Yine Kazan dilinden bir anlatımı olan bu metinde Kazan kendisini sırasıly dağlara, kara denize (?) ${ }^{33}$, buğraya, kaplana, aslana ve son olarak da buluta benzetir:

Koba koba taglar-1dum ${ }^{34}$ er buyaldırdum buşkunumda ben Kazan

Kayın-akar kara deniz-idüm er buyaldurdum çevligümde ben Kazan

Kaytabanun bugras1-idüm er buyaldurdum kökredükde (ben Kazan)

Kapkayada ayrar arslan-idüm kaplan-idüm (er buyaldurdum ayradukda) ben Kazan

Saru sazda arslan-idüm er buyaldurdum haykurdukda (ben Kazan)

Kara bulud örgüni-idüm kara denizden su alup yere barçın(?) satar-idüm, ben Kazan (3/55-

57)

Bu metnin ilk sözlerini Tezcan "Yüksek yüksek dağlar idim. Er bunaltırdım tipilerim tuttuğunda (kar firtınamda) ben Kazan” şeklinde çevirmiştir (2020: 229). Okunuşu ihtilaflı olan TGLDAYDWM (?) yazılışl kelimeyi taglar okuyan ve kaba > koba 'büyük' açıklamasını yapan ${ }^{35}$ Tezcan, “Ozan, Kazan'ı yüksek dağlara, Kazan'ın öfkesini de dağlarda kopan fırtınaya benzetmiştir." yorumunu yapmaktadır. Tezcan'ın işaret ettiği korku salma duygusu, bu övgü metninin tamaminda etkindir.

32 Kara bulut örgünü ifadesi Osmanoğlu [Al-i Osman] için de kullanılmıştır (T.O.1/9) ancak bu övgü sözünün Kazan için kullanışı daha detaylıdır.

33 Kara deniz ifadesi kara dağ gibi genel bir anlam taşıyabilir. Bu konuda kesin bir delil yoktur.

34 Kırzıoğlu, bu cümleyi Kuba- kuba tıgılda(r)-ıdum şeklinde okumuştur (2000: 108).

35 Günbed yazmasında kuba (veya koba) deyimi deve (kuba ner) ve kaz (kuba kaz) ayrıca göğüs (kuba döş) için kullanılmaktadır (G.8a/4-6; 4b/5; 8a/11). Ancak kuba döş bir yerde de kaba döş olarak yazılmıştır (G.10a/13). Naşirler bu konuda muhtelif açılamalar yapmıştır. 


\section{ग(৫)}

Bu okuyuşu doğru kabul edersek bu soylama da 17. soylama gibi dağları anarak başlamış olur. Dağlar, buşkun denilen firtınasıyla "er bunaltan" olarak anılmış olacaktır. Dağların bir ürkütücülüğü, er bunaltması, dumanı dolayısıyla yolu kaybettirmesindendir. Dağ- duman ilişkisinden sonra deniz (ırmak?), buğra, aslan, kaplan gibi unsurlar Kazan için teşbih unsuru olmuştur.

Burada düşmana korku salmayı ifade eden kökremek, ayramak, haykurmak (sokramak - Tezcan) gibi fiillerle 'buşkun' ve 'bulutun gürlemesi' (belki denizin çalkanması ${ }^{36}$ ) uyumlu ve anlamlı görülmektedir. Bulut, "hiddet gösterme ve düşmanı sindirme" ile ilgili klişelerin bir parçasıdır ve bu yüzden aslan, deve gibi yiğitlik sembolü hayvanlarla birlikte anılmıştır. Bu hayvanlar acı̆̆ı tutanda dehşet saçan yırtıcılardır.

\section{Kara Bulut Örgünü}

Kazan için kullanılan kara bulut örgün $\ddot{3}^{37}$ ifadesi, 17. soylamanın başlangıcını anlamada kilit bir önem arz eder. Tezcan'a göre KRA BLWD AWRGWNY yazılışlı bu söz, 'kara bulut kasırgası' anlamındadır (2020: 231). Günbed yazmasının 12. soylama başlangıcında Kara bulut erdemidür gökde örilmak. (G.16a/4) denilmektedir. Bu ifadeyi güçlü bulutların yükseldiği, fırtına koparıp gürlediği şeklinde düşünebiliriz (bk. 29. dipnot). Bulutla ilgili bu özdeşleştirmede bulutun 'gürleme’ ve ‘kasırgaya dönüşme' anlamı göz önünde bulundurulmalıdır.

Kazan'in kara bulut olup gürlemek istemesi, kendi dilinden de ifade edilmiştir. Oğlu Uruz’un tutsak olduğu boyda Kazan, oğlu için şu şekilde feryat eder:

Âsumanlı gökde kara bulut oluban

Kâfirün üzerine gürleyeyim

Ağ yıldırım olub şakıyayım,

Kâfiri kamış gibi od oluban yandurayım. (D.76a/6-8)

36 Bulutun denizden su alı yere (?) satması bilgisi, tabiat gözlemindeki bir dikkat olarak görülebilir. Fakat bu barçın ve satar-idüm kelimelerinin gerçekte ne olduğu tartışmalıdır. Gökyay, barçın'ı bârân 'yağmur' olarak okumuştur. Tezcan, bu okuyuşu mantıklı bulur, bu yorumu olumlayan örnekler sıralar fakat Edgüer'in barcın okuyuşunu barçın diye düzelterek ifadeyi "Bütün dünyaya barçın satan bendim." şeklinde çevirir ve İpek yoluna, ipek üretimine dair atıflarda bulunur (2020: 231-236). Haykırmak, kükremek gibi fiillere paralel olan deyimin, deniz söz konusu olduğunda 'ipek satmak' olması anlaşılır değildir.

37 Demir, bu ifadeyi 'kara bulut gölgesi' olarak çevirmiştir (2019: 70). 
Bu sözlerin devamında Kazan, abdest alıp dua ettikten sonra deve gibi kükrer, arslan gibi angrar, nara vurup haykırır. Bu saydığımız iki metinde de bulut, Kazan'ın aslana kaplana benzetilmesinde olduğu gibi bir teşbih unsurudur, "kendisine benzetilen"dir. $\mathrm{Bu}$ sebeple bulut olmak bir meydan okumadır, tehdittir ve intikama işaret eder.

Kazan Bey'in bu hikâyede yine oğlu için kullandığı Sen gideli ağlamağum gökde iken yere indi (D.75a/2-3) sözü de dikkate değer bir ifadedir. Ağlamağın gökte iken yere inmesi, Kazan'ın kendisini bir bulut olarak tanımlamasıyla anlaşılabilir bir sözdür. Ancak burada farklı olarak bulut, bir öfke hâlini değil, ağlama hâlini temsil eder. Kazan Bey, oğlu Uruz'un acısıyla ağlamaktadır. Sevindiklerinde ıssız yerin kurdu gibi uluşan kahramanların ağlaması, Dede Korkut Kitabı'nda böğürü böğürü ağlamak (D.35b/9) deyimiyle tarif edilir. Bazen bütün beyler böğrüşerek ağlarlar (D.48a/1). Böylece hüzün simgesi olarak bile bulutun 'sert' bir anlamda kullanıldı̆̆ını söyleyebiliriz. Kahramanların ağlaması naif bir ifadeyle anılmamaktadır.

Kazan'ın kayın akar kara deniz-idüm "deli deli akan kara denizdim" 38 demesini de bir şiddet anlamı içinde okumak gereklidir. Bulutların gürlemesi gibi denizin köpürmesine de bir öfke anlamı verildiği açıktır. Nitekim köpürmek mecazen 'çok kızmak' anlamında kullanılan bir kelimedir (Güncel Türkçe Sözlük). Tezcan, kayın-akar' daki ak- fiilinden dolayı deniz kelimesi ile ırmağın kast edilmiş olabileceğini söylemiştir (2020: 230). Denizin kayın akması'ndan ne anlamamız gerektiğini ortaya çıkaran bir ifade, yeni yazmada geçen, yine Kazan'1 methetmek için kullanılan kaynar deniz kursaklı (G.12b/3) ifadesidir. Öfkenin yiğitlerin çok övülen bir özelliği olduğu zeminde kaynar deniz kursakl, kızgın bir homurdanışı, "burundan solumayı" ve "gürlemeyi" ifade eden bir övgü sözü olmaktadır. Yine bir öfke tarifi olan Delü Karçar ağzın köpüklendürdi (D.43b/3) ifadesi öfke - deniz eşleşmesinin mantığına 1şık tutar. Böylece deniz de, bulutun

38 Bu ifadeyi 'kaynayarak' olarak anlamak mümkün görünmektedir. Clauson, kaynar ögüz keçigsiz bolmaz sözündeki kaynar kelimesini 'acele, hızlı' olarak çevirmiştir (1972: 697a). Ayrıca, kayın- fiilinin eski formu olarak kay- kökünü önermiştir (1972: 678a). Tezcan, bu kelimeyi kamın akmak 'kanlı kanlı akmak' ile ilişkili görür ve 'sürekli akmak’ anlamına geleceğini söyler (2020: 230). Dede Korkut Kitabı'nda geçen kaynar deniz kursaklı ve ăğın köpüklendirmek ifadeleri kayın - kaynamak arasındaki ilişkiyi anlamlı kılmaktadır. Rize ağzında yaygın olarak kullanılan hayin kelimesinin de ‘şiddetli, tazyikli, deli deli, çok fazla’ gibi anlamlara gelmesi ilginç bir tesadüftür. Suyun şiddetli ve hızlı akmasına hayin akmak denilir. Benzer anlamlar ve kullanımlar kayim kelimesi için de söz konusudur. (Bk. Öztürk, 2005: 646). 
kükremesine çok benzer bir ilişki ile kızgınlı sembolleri cümlesine katılmaktadır.

\section{Bulut Teşbihinin Yan Unsurları: Çiskin ve Duman}

Çiskin ve duman, puslu bir havayı ifade etmektedir ve Kazan da bu yazmada dumanl dağ börisi (G.25a/6) olarak övülmüştür. Alçak yerler ve yüce dağlar arasındaki zıtlıkta, dağlar başı dumanla, ovalar çiskin ile birlikte anılmıştır. ${ }^{39}$

Güncel Türkçe Sözlük'te 'çiseleyen yağmur, çiseleyen yağmurdan hafifçe ıslanmış' anlamıyla geçen çiskin kelimesinin ağızlarda sisli yağmurlu hava için kullanıldığ 1 da görülmektedir. Kamus-i Türkîde çiskin'le beraber çisendi ve çisimek kelimeleri geçer (1989: 527). Azerbaycan Türkçesinde çişkin şeklinde de görülen bu kelime çi-g kökünden gelmektedir ve çise, çiselemek (çis-g-elemek), çisni, çisnemek, çisenti gibi kelimelerle bağlantılıdır. Kelime sisli, rutubetli hava, ince yağmur serpintisi gibi anlamlara gelmektedir (Gülensoy, 2007: 244). Çiskin'e verilen anlamlar, çiskin ile duman arasında belirgin bir fark olmadığını düşündürür. Nitekim bu iki kelimeyi sözlüklerde birbirinin karşllı̆̆ olarak görmek de mümkündür (Akdoğan, 1999: 838). Halk şiirinde çiskin ve dumanın birlikte zikredilmesinin örnekleri vardır:

Sen duman ol ben çiskin / Çekilek dağa bele.

Dağlar çiskin olur mu? Duman, çiskin olur mu? (Karaağaç-Açıkgöz, 1998: 64, 496).

Bulut, sis ve duman birbirine anlamca yakındır ve sis yeryüzüne daha yakın su buharı olarak anlaşılır (Şirin, 2017). Bizim metnimizde aynı hava durumunun bir karşıllı̆ı olarak yakında ve alçakta bulunanın çiskin, uzakta ve yüksekte bulunanın ise 'duman' olarak adlandırıldığını düşünmek mantıklıdır. Alçaklara, dağ yamaçlarına, vadilere çöken dumanın uzun süre kalkmaması, bulutun bunaltıcı gücüne yorulabilecek bir tablodur. Bu sebeple çökmek deyiminin 'düşmanı basmak, düşmanı çaresiz duruma düşürmek' anlamıyla birleştiğini ifade etmiştik. Dumanıyla meşhur dağ başının anılması, düşmanın en güçlüsünü,

39 Alçak ava yer ifadesi önceki yazmalardaki önemli bir tensih hatasını düzeltir. Beyrek hikâyesinde hava şeklinde yazılmış olan kelime, alan alçak hava yerden gelen argış sözünü çözümlemede sıkıntı oluşturmuş, Ergin, bu ifadeyi “düz engin havadan yer" olarak almış, Tezcan ise kelimenin hova olup yanlış yazılmış olabileceğini söylemişti. Bu ifade üzerindeki ihtilafa dikkat çeken Zahidoğlu, ifadeyi "Alacakaranlık havada (sabahın alacakaranlı̆ında) muhterem yerden gelen kervancı. (2015: 161) olarak tevil etmişti. 


\section{ग(৫)}

“başını” ifade ediyor gibidir. Dağ başı bile Kazan'ın kudreti karşısında acizdir. Burada Dede Korkut Kitabı'nın deyimleri arasında sayılan ve kahramanlar için kullanılan yel gibi yetip yellim gibi yapışmak deyimi de hatırlanabilir.

Dağlar başı birçok türküde olduğu gibi dumanla yâd edilmektedir. Alçak ava yer ile uca dağlar arasında bir zıtlık vardır. Bu da çiskin ve duman kelimelerinin sıralanmasında etkili olmuştur. ${ }^{40}$ Topkapı Oğuznâmesi'nde benzeri bir karşıtlık "Yuca-yerden alçak yere göz-gözeden" (T.0.2/46) şeklinde, Beyrek için söylenmiştir. Hem alçak yerlerin hem yüksek yerlerin bu ifadede anılması, bulutun dolayısıyla Kazan'ın muktedirliğini, hükmünün her yere geçebildiğini göstermek içindir.

\section{Kazan'in Dumanlı Dă̆ Börisi Vasfı}

Bulut teşbihinin bir tamamlayıcısı olarak sayılan çiskin ve duman, Kazan'la ilgili başka bağlantıları da hatıra getirmektedir. Salur Kazan'ın Günbed yazmasında yapılan bir takdimi dumanlı dağ börisi (G.25a/7) şeklindedir. Kurtlar puslu havayı sever atasözünü hatırlatan bu deyim ile Kazan'ın dağlara ve tabiatın sert şartlarına hâkim olması övülüyor olsa gerektir. 17. soylamada geçen yüce dağlar başına duman olmak deyimiyle "zor yollarda kılavuzluk" etmenin ve yol şaşırmamanın da bir ilgisi kurulabilir. Topkapı Oğuznâmesi'ndeki Kazan'la ilgili kısımda ve Dresden'deki tutsak olma hikâyesinde Kazan'ın dumanlı havada göz gözü görmezken bile yolları bulabildiğine, varacağı yere vardığına, Oğuzlara kılavuzluk yaptığına dair işaret vardır:

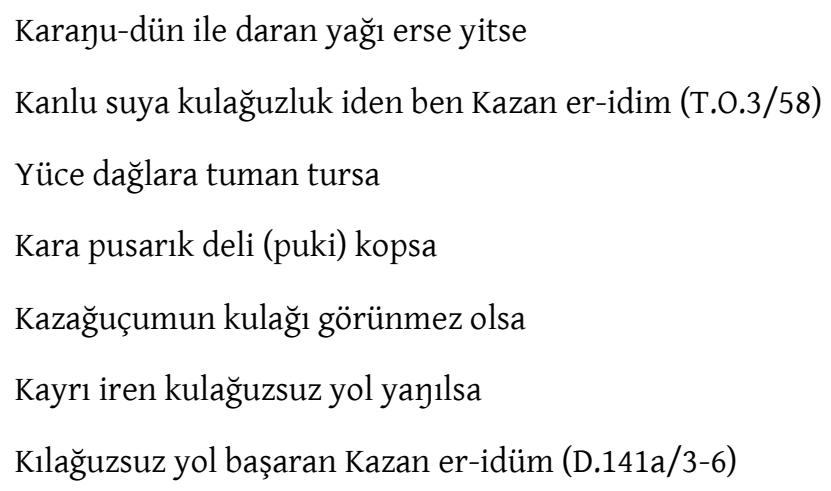

Bu iki metinde Kazan'ın yol bulabilirliği, birbirinden farklı zaman ve mekân zarfında verilmiştir. Topkapı Oğuznâmesi'ndeki soylamada "karanlık gece" ve "kanlu su", Dresden metnindeki soylamada ise "dumanlı hava" (gündüz) ve "yüce

40 Rzasoy “su sitixiyası” ile ilişkili gördüğü bu unsurları duman, bulut, çiskin şeklinde sıraya koymuştur. 


\section{ग(৫)}

dağlar”, Kazan'ın “yol başarması” tablosunu tamamlamaktadır. Kazan'ın yol bulmadaki yeteneğinin iki ayrı metinde anılması önemlidir. Dede Korkut metinleri içinde Salur Kazan'ın tek başına yaptığı bir yolculuk, Kazan'in evinin yağmalandığı boyda anılmaktadır. Günbed yazmasında anlatılan Kazan'ın ejderhaya rast gelmesi olayı da yine böyle tek başına bir yolculukta ve karankluk karışınca olmuştur. Yeddi başlı ejderhanın gözleri karanlıkta meşale gibi parlamıştır.

Kazan'ın kesif dumanlar içinde yol bulması, ıssız ve tehlikeli dağlarda dumanlara karışıp gitmesi, kahramanın dumanla ve bulutla yâd edilmesine, yüksek ve alçak yerlere hâkim olmasına bir başka zemin olarak düşünülebilir. Aynı şekilde duman gibi düşmana korku salması, onları şaşırtması da söz konusudur. Bu konu Kırgızların Kococaş Destani'ndaki büyülü sahneleri hatırlatacaktır. Kococaş Destanı'nda bir "kayberen" olan Sureçki adlı geyik, ardından "kara duman salarak" izini kaybettirmektedir.

Burada gözden kaçırmamak gereken önemli bir husus, metni oluşturan bu kelimeleri yorumlarken kullandığımız hikâyelerin, metni sadece kendi içinde değerlendirdiğimizde ortaya çıkacak bağlantılar olmadığıdır. Kelimeler bağlı bulunduğu ana metnin epik dünyasından bağımsız olarak değerlendirildiğinde birçok anlama ve bağlantıya ulaşmak olası görünmemektedir.

\section{Sonuç}

Günbed (Türkmen Sahra) yazmasının çok önemli bir parçası olan ve Salur Kazan'ın bir destan kahramanı olarak "kendi dilinden” övgüsünü içeren 17. soylama, "gökyüzünde bulut olmak" şeklinde bir tabloyla başlamaktadır. Soylamanın giriş sözlerini şu şekilde günümüz Türkçesine yaklaştırmak mümkündür:

Buruldumsa saraldımsa, gökyüzünde bulut oldum.

Alçak ova yerlere çiskin oldum

Yüce dağlar başına duman olan Gazan idim. (G.20a/1-3)

"Gökyüzüne" temas etmekle bu başlangıç, yazmadaki soylamaların genel eğilimine uygunluk gösterir. Fakat burada bir gök olayı, kahramandaki bir vasfa karşılık olarak anılmaktadır. Anılan doğa unsuru ile kahramanın benzerlik ilişkisinin ne olduğu, elimizdeki metnin tahlili için cevaplanması gereken bir sorudur. 


\section{Ј(৫)}

Metnin zengin çağrışımları, bulutla ilgili etimolojik bağlantılar ve fiziksel hususlar, bu soylama başlangıcının yorumlanmasında bir çeşitlilik ortaya çıkarmış, kelimelerin anlam kabiliyeti yoklanmıştır. Sonuç olarak bu soylama girişi için iki farklı okuyuş ve en az beş farklı yorumlayış söz konusu olmuştur. Ancak bu yorumların çizdiği tablodan metnin temel bağlamına ulaşmak ve bulut mecazına neden başvurulduğunu anlamak olası değildir. Tahavvül ise çizilen destan karakterine uzaktır.

Metinde okuyucuyu görkemli bir kahramanlık anlatısına hazırlayacak, güçlü, kesin ve çok sert bir başlangıç olması gerekir. Böyle bir girişle Salur Kazan, ejderhayı yendiği hikâyesine telmih yapacak, yuvarlanan kaya parçasını tutması gibi kimsenin yapamadığı ve etrafındaki beyleri şaşkına çeviren kahramanlıklarını anlatarak övünecektir. Bayındır Han'dan vekilliği almasını ve padişah kızı Boyu Uzun Burla Hatun'u cüldü (ödül) kapmasını bile bir "hakkını alış” edasıyla, büyüklenerek ve yer yer mizahi bir dil kullanarak anlatan Kazan'ın bu hâkim üslubu, bizi vurucu bir ifade tarzına götürecek en önemli işaretlerdir.

Bizim bu soylama başlangıcını anlamlandırma çabamız, metnin epik bağlamından hareketle bulutun bir gazap sembolü olarak anıldığ sonucunu vermiştir. İlk kelimenin okunuşundaki ihtilafta bize göre doğru okuyuş, burulmak okuyuşudur. Ancak burulmak ve saralmak fiillerinin bulut kelimesiyle ilişkisi metaforik bir ilişki olarak okunmalı, ifade 'kızdığımda, hiddetim tuttuğunda' olarak alınmalıdır. Bu sözün paralel bir ifadesi acığı tutmak'tır. Kazan'ın bulut olması, bulutun eril ve hükmedici bir varlık olarak tasavvur edilmesine dayanan ve Kazan'ın "kükremesi”ni, düşmana dehşet salmasını ifade eden bir benzetmedir. Bulut'un korku üzerine temellenen mitolojik anlamı da bu sonucu gerektirir. Böylece Salur Kazan'ın övgüsü, en yukarıdan, göksel bir konumdan başlamış olmaktadır.

Burulma ve saralma'nın kızgınlığa işaret eden anlamları konusunda sözlükler önemli ipuçları vermektedir. Ancak edebî metinlerin tanıklı̆̆ı kelimelerin bu anlamlarını teşhis için elimizdeki en güçlü kanıtlardır. Bur- sarikilemesini burk sark ve bura sara örnekleri ile birlikte değerlendirmek metni büyük ölçüde aydınlatmaktadır. Bununla birlikte geliştirdiğimiz yorum Dede Korkut metinlerinin anlam dünyasına dayanmakta, ayrıca Kazan şahsında bir yiğidin övgüsü olarak her zaman geçerli olacak bir ilkeden beslenmektedir. Bu 


\section{ग(৫)}

ilke, kahramanlığın 'güç gösterme' anlamından bağımsız düşünülemeyeceğidir. Savaşma kabiliyetinin bir bileşeni olarak öfke duygusu güç gösterme denkleminin ayrılmaz bir unsurudur ve anlatının kurgusu için elzemdir. Kazan için kullanılan kara bulut örgünü, kaynar deniz kursaklı gibi ifadeler de kahramanın gazabına ve şiddetine işaret etmektedir.

Çiskin ve duman, bulutun neticesi ve aynı hava durumunun görünümleri olarak bulutla yapılan teşbihi tamamlar; bunaltıcı ve kahredicidir. Burada bulunma hâli yerine yönelme hâli kullanılması, meydan okuma anlamını daha vurgulu hâle getirmiştir. Kazan'ın dumanla ilişkilendirilmesi ayrıca onun dumanlı dağ börüsü olarak vasf edilmesini ve yol bulma konusundaki yeteneğini hatırlatabilir.

17. soylama metninin zengin bir çağrışım dünyasından beslenmiş olduğu ve soylamada Kazan'la ilgili önemli hikâyelerin anahtarlarını verecek kelimelerin rastgele seçilmediği anlaşılmaktadır. Bu yüzden metni Dede Korkut metinlerinin bütününden ve ana teması güç göstermek olan destan dünyasından ayrı değerlendirmek, pek çok bağlantının sağlayacağı anlam zenginliğini ve metnin edebî kıymetini anlamaya engel olacaktır.

Salur Kazan'ın destansı kişiliğini çerçeveleyen ve Kazan adını kazanış hikâyesine de yer veren bu önemli soylama, giriş cümleleriyle de Günbed yazmasının ve bütün Dede Korkut anlatılarının kilit metinlerinden biri olmaktadır.

\section{Kisaltmalar}

D. = Dresden nüshas1.

DS = Derleme Sözlüğü (1993).

G. = Günbet yazmasi .

T.O. = Topkapı Oğuznamesi.

\section{Kaynakça}

Aça, M. (2007). Destan ve Masal Anlatımı Zamanı ile Ortamını Belirleyen İnançlar Nelerdir? In Türkmen, F. \& Gülsevin G. (eds), I. Uluslararası Türk Dünyası Kültür Kurultayı, 09-15 Nisan 2006 Çeşme-İzmir, Bildiri Kitabl-I (pp. 13-22). Ege Üniversitesi Türk Dünyası Araştırmaları Enstitüsü. 
Akdoğan, Y. (1999). Azerbaycan Türkçesinden Türkiye Türkçesine Büyük Sözlük. Beşir Yayınevi.

Asker, R. (2019). Kitadi-Dadə Qorqud’un Üçüncü Elyazması. Azərbaycan Milli Elmlər Akademiyası.

Axundov, A. et al. (2006). Azərbaycan Dilinin İzahlı Lüğəti I-IV. Şərq-Qərb.

Ayverdi, İ. (2011). Misalli Büyük Türkçe Sözlük: Asırlar Boyu Tarihî Seyr İçinde. Kubbealtı Yayınları.

Azmun, Y. (2018). What We Learn From Turkmen Carpets. Çukurova Üniversitesi Türkoloji Araştırmaları Dergisi, 3(2), 36-53.

Azmun, Y. (2019). Dede Korkut'un Üçüncü Elyazması, Soylamalar ve İki Yeni Boy İle Türkmen Sahra Nüshası, Metin-Çeviri-Sözlük-Tıpkıbasım. Kutlu Yayınevi.

Azmun, Y. (2020). The New Dädä Qorqut Tales from the Recently-Found Third Manuscript of the Book of Dädä Qorqut. Journal of Old Turkic Studies, 4(1), 16-27.

Clauson, S. G. (1972). An Etymological Dictionary of Pre-Thirteenth Century Turkish. Oxford University Press.

Çağbayır, Y. (2019). Kutadgu Bilig, Çeviri Yazı ve Günümüz Türkçesi. Ötüken Neşriyat.

Demir, N. (2019). Dede Korkut Destanı. Ötüken Neşriyat.

Dilek, İ. (2002). Altay Destanları: Er Samır, Ak Tayçı, Kökin Erkey, Altay Buuçay, Malçı Mergen, Kozın Erkeş, Közüyke. Türk Dil Kurumu Yayınları.

Dilek, İ. (2018). Mitolojilerde ve Türk Destanlarında Köpük. Türk Dünyası Dil ve Edebiyat Dergisi, 46, 67-90

Doğan, E. (2011). Türkiye Türkçesinde Cinsiyet Kategorisinin İzleri. Uluslararası Sosyal Araştırmalar Dergisi, 4(17), 89-98.

Durak, N. (2010). Çingiz Han'ın Yetiştiği Kültürde Korku ve Korku Salma Taktikleri. In Naskali-Gürsoy, E. (Ed.), Korku Kitabı (pp. 223-240). Kitabevi.

Ekici, M. (2019). Dede Korkut Kitabı Türkistan/Türkmen Sahra Nüshası Soylamalar ve 13. Boy-Salur Kazan'in Yedi Başlı Ejderhayı Öldürmesi-. Ötüken Neşriyat.

Ercilasun, A. B. \& Akkoyunlu, Z. (2014). Kâşgarlı Mahmud: Dîvânu Lugâti't-Türk GirişMetin-Çeviri-Notlar-Dizin. Türk Dil Kurumu Yayınları.

Eren, H. (1999). Türk Dilinin Etimolojik Sözlüğü. Bizim Büro Basımevi.

Ergin, M. (1971). Dede Korkut Kitabı. Milli Eğitim Basımevi. 
Esin, E. (1970). Evren (Selçuklu San'atı Evren Tasvirinin Türk İkonografisinde Menşe’leri). Türk Tarih Kurumu Basımevi.

Gökçimen, A. (2010). Türkmenistan'da Bir Yağmur İyesi “Burkut Ata”. Bilig Dergisi, $52,69-78$.

Gülensoy, T. (2007). Türkiye Türkçesindeki Türkçe Sözcüklerin Köken Bilgisi Sözlüğü III. Türk Dil Kurumu Yayınları.

Güllüdağ, N. (2001). Divanü Lugat-it-Türk ve Nogay, Kumuk, Karaçay-Malkar, Yeni Uygur Türkçesinde At ile İlgili Atasözleri Üzerine Bir Değerlendirme. In Gültekin, A. (Ed.), I. Ulusal Karşılaştırmalı Edebiyat Sempozyumu Bildirileri, Eskişehir, 6-8 Aralık 2001 (pp. 160-171). Osmangazi Üniversitesi Yayınları.

Hacıyev, A. Türkman Kitabı: Oxunuş va Şərhlər. Dada Qorqud. 4(67), 3-60.

Haznedaroğlu, A. (2020a). Salur Kazan'ın Ad Kazanması Üzerine. Dede Korkut Uluslararası Türk Edebiyatı Araştırmaları Dergisi, 9(21), 163-185.

Haznedaroğlu, A. (2020b). Günbed Yazmasında Bir Karşı Taraf Temsili Olarak Ala Demir Kâfir Han Ve Kazan'ın Üç Hüneri Hakkında Bir Değerlendirme. In Uluç, G. \& Şimşek, N. D. (Eds.), Uluslararası Dede Korkut Bilgi Şöleni ve Deli Dönmez'e Ad Vérme Çalıștayı Bildiriler Bétiği, 11-12 Haziran 2020 (pp. 239-253). Kutlu Yayınevi.

Karaağaç, G. \& Açıkgöz, H. (1998). Azerbaycan Bayatıları. Türk Dil Kurumu Yayınları.

Kırzıoğlu, M. F. (2000). Dede Korkut Oğuznâmeleri. Atatürk Kültür Merkezi.

Koçak, Z. C. (2018). Bulut Motifinin Arkaik Temelleri ve Hz. Peygamber'i Gölgeleyen Bulut Rivayetleri. Ankara Üniversitesi İlahiyat Fakültesi Dergisi, 59(1): 183-202.

Kuanışbayeva, A. (2002). Formül Nazariyesi ve Koblandı Batır Destanındaki Formüller. Gazi Üniversitesi Sosyal Bilimler Enstitüsü. (Yayımlanmamış Yüksek Lisans Tezi).

Nurutdinov, F. A. H. (1991). Mikail Baştu, İbn Şams Tebir, Şan Kızı Destanı. Kültür Bakanlı̆̆ı Yayınları.

Ögel, B. (2014). Türk Mitolojisi II. Türk Tarih Kurumu Yayınları.

Ömer Seyfettin (2009). Bütün Hikâyeleri 4-6. Üç Harf Yayınları.

Ömer Seyfettin (2017). Harem. Ötüken Neşriyat.

Özçelik, S. (2009). Dede Korkut Metinleri Üzerinde Tespitler. Türk Dünyası Incelemeleri Dergisi, 9(2), 155-164.

Özçelik, S. (2019). Dede Korkut Oğuznamelerinin Kaç(ınc1) Nüshası Bulundu? Türk Dili Dergisi, 117(812), 48-56. 


\section{0}

Özçelik, S. (2020). Dede Korkut Oğuznameleri Üzerine -Günbed Nüshası Işı̆̆ındaDüzeltme Teklifleri. Türk Dünyası Dil ve Edebiyat Dergisi, 49, 7-20.

Öztürk, Ö. (2005). Karadeniz Ansiklopedik Sözlük. Heyemola Yayınları.

Quliyev, B. (2020). Kitabi-Dadəm Qorqud ve Onun Türkman Sahra Nüsxasl, (Transliterasiya, Fotofaksimile, Qəyd ve Şərhler). Türkkitab.

Rafraf, İ. (2020). Yağsa Yağmur Daşsa Çaylar, Dede Korkud Araşdırmaları Türkmen Sahra Kitabı. Ozan Dergisi, 1(6), 1-150.

Rzasoy, S. (2020). "Kitabi Türkmen Lisani” Oğuznaməsinin Transmediativ Strukturu və Ritual-Mifoloji Semantikası. Bakı: Azərbaycan Milli Elmlər Akademiyası Folklor Institutu.

Serrafî, A. et al. (2019). Dedem Korkud'un Türkmen Sahra Kitabı. Ozan Dergisi, 1(35), 1-308.

Sertkaya, O. F. (1968). Mỉrācnāme, Metin-İndeks. İstanbul Üniversitesi Edebiyat Fakültesi Türk Dili ve Edebiyatı Bölümü. (Yayımlanmamış Mezuniyet Tezi).

Sertkaya, O. F. (2019a). Dede Korkut Kitabı'nın Kaç Yazma Nüshası Var? Dede Qorkud, Azerbaycan Milli Elmler Akademiyası Folklor İnstitusu, 3, 21-27.

Sertkaya, O. F. (2019b). Azmun, Y. Dede Korkut'un Üçüncü Elyazması, Yeni Soylamalar ve Boylar (Hikâyeler) ile Türkmen Sahra Nüshası, Giriş-Metin-ÇeviriSözlük-Tipkıbasım, Kutlu Yayınevi, İstanbul, 2019. Journal of Old Turkic Studies, 3(2), 637646. (Tanitma)

Sertkaya, O. F. \& Uzuntaş, H. (2020). Dede Korkut'un Günbed Yazması Üzerine Araştırmalar ve İncelemeler. Bilge Kültür Sanat Yayınları.

Seyidəliyev, N. (2007). Azərbaycan Dilinin Sinonimlar Lüğəti. Şərq-Qərb.

Shahgoli, N. K. et al. (2019). Dede Korkut Kitabı'nın Günbet Yazması: İnceleme. Metin, Dizin ve Tıpkıbasım. Modern Türklük Araştırmaları Dergisi, 16(2), 147-379.

Şemseddin Sâmi (1989). Kâmûs-ı Türkî. Enderun Kitabevi.

Şirin, H. (2017). Türkçede Bulut. In Karahan, L. (Ed.), Türklük Biliminin Ulu Çınarı Zeynep Korkmaz Armağanı (pp. 373-382). Türk Kültürünü Araştırma Enstitüsü Yayınları.

Tekin, T. et al. (1995). Türkmence-Türkçe Sözlük. Şafak Matbaacllik.

Tekin, T. (1968). A Grammar of Orkhon Turkic. Indiana Universty.

Tezcan, S. (2018). Dede Korkut Oğuznameleri Üzerine Notlar. Yapı Kredi Yayınları.

Tezcan, S. (2020). Topkapı Sarayı Oğuznâmesi, İnceleme. Yapı Kredi Yayınları. 


\section{J(ఠ)}

Tulu, S. (2020). Dede Korkut Oğuznâmesi Boylar ve Soylamalar Günümüz Türkçesine Sözlü Çevirisi Dresden Nüshası ve Günbed-i Kâvus / Türkmensahra El Yazması Esasında. Ankara: Nobel Yayın.

Tulum, M. \& Tulum, M. M. (2016). Oğuznameler, Oğuz Beylerinin Hikâyeleri. Atatürk Kültür Merkezi Başkanlığı Yayınları.

Türkiye’de Halk Ağzından Derleme Sözlüğü I-XII (1993). Türk Dil Kurumu Yayınları.

Uçar, E. (2020). Dede Korkut Kitabı'ndaki Bir Soylama Üzerine. Eski Türk Edebiyatı Araştırmaları Dergisi, 3(1), 213-240.

Uçar, E. (2019). Orhun Yazıtlarındaki er- bar- İkilemesi Üzerine. Journal of old Turkic Studies, 3/2, 2019: 471-501

Yılmaz, G. K. (2013). Hakas Destanları 4: Altın Taycı. Türk Dil Kurumu Yayınları.

Zahidoğlu, V. A. (2015). Dede Korkut Kitabı'nda Tipik Bir İstinsah Hatası Üzerine. Türk Dünyasi İncelemeleri Dergisi, 5(2), 159-170.

Zieme, P. (1991). Die Stabreimtexte der Uiguren von Turfan und Dunhuang. Studien zur alttürkischen Dichtung. Bibliotheca Orientalis Hungarica. 